\title{
A Structural View of SARS-CoV-2 RNA Replication Machinery: RNA Synthesis, Proofreading and Final Capping
}

\author{
Maria Romano ${ }^{1,+}{ }^{1}$, Alessia Ruggiero ${ }^{1,+}$, Flavia Squeglia ${ }^{1, \dagger}$, Giovanni Maga ${ }^{2}$ \\ and Rita Berisio ${ }^{1, *}$ \\ 1 Institute of Biostructures and Bioimaging, IBB, CNR, 80134 Naples, Italy; maria.romano@cnr.it (M.R.); \\ alessia.ruggiero@cnr.it (A.R.); flavia.squeglia@cnr.it (F.S.) \\ 2 Institute of Molecular Genetics, IGM, CNR, 27100 Pavia, Italy; giovanni.maga@igm.cnr.it \\ * Correspondence: rita.berisio@cnr.it; Tel.: +39-081-2534507 \\ + These authors contributed equally to this work.
}

Received: 24 April 2020; Accepted: 19 May 2020; Published: 20 May 2020

\begin{abstract}
The current coronavirus disease-2019 (COVID-19) pandemic is due to the novel coronavirus SARS-CoV-2. The scientific community has mounted a strong response by accelerating research and innovation, and has quickly set the foundation for understanding the molecular determinants of the disease for the development of targeted therapeutic interventions. The replication of the viral genome within the infected cells is a key stage of the SARS-CoV-2 life cycle. It is a complex process involving the action of several viral and host proteins in order to perform RNA polymerization, proofreading and final capping. This review provides an update of the structural and functional data on the key actors of the replicatory machinery of SARS-CoV-2, to fill the gaps in the currently available structural data, which is mainly obtained through homology modeling. Moreover, learning from similar viruses, we collect data from the literature to reconstruct the pattern of interactions among the protein actors of the SARS-CoV-2 RNA polymerase machinery. Here, an important role is played by co-factors such as Nsp8 and Nsp10, not only as allosteric activators but also as molecular connectors that hold the entire machinery together to enhance the efficiency of RNA replication.
\end{abstract}

Keywords: SARS-CoV-2; COVID19; RNA replication; protein structure; infectious disease

\section{Introduction}

Coronavirus disease-2019 (COVID-19) is a respiratory disease caused by a novel enveloped, positive-sense, single-stranded RNA betacoronavirus, denoted as SARS-CoV-2. In December 2019, a cluster of patients in the Chinese city of Wuhan was diagnosed with a pneumonia of unknown etiology. At the time of writing, SARS-CoV-2, has caused over $4 \times 10^{6}$ confirmed cases and $2.98 \times 10^{5}$ fatalities worldwide. The efficiency of disease transmission, the fact that a significant proportion of infected people develop pneumonia and the increased risk of lethality in fragile patients such as the elderly, patients with immunodeficiency and people affected by chronic respiratory and heart diseases, make SARS-CoV-2 infection a serious global health threat. Consequently, on January 2020, the World Health Organization (WHO) declared the situation a public health emergency of international concern and in March 2020, it declared COVID-19 a pandemic threat. The scientific community has responded promptly to the emergency by focusing heavily on accelerating research and innovation, as witnessed by the copious amount of recent literature. This has set the foundation for understanding the molecular determinants of the disease and the development of targeted therapeutic interventions [1-3]. These ground-breaking studies have shown that SARS-CoV-2 shares $79.5 \%$ of its genome with 
SARS-CoV [1], thus it is sufficiently divergent from SARS-CoV to be considered a new human-infecting betacoronavirus [3]. Genome sequence analysis has revealed SARS-CoV-2 phylogenetic relationships with bat-derived SARS-like coronaviruses, which suggests a zoonotic origin [1]. However, much of what we can infer about the biology of SARS-CoV-2 comes from previous studies on the SARS-CoV. Starting from these data, the molecular mechanisms underlying the evolution, adaptation, and spread of this virus warrant urgent investigation.

SARS-CoV-2 gets into the cell through recognition by the spike glycoprotein present on the surface of the virus envelope of the angiotensin converting enzyme 2 (ACE2) receptors, as previously observed for SARS-CoV [4,5]. It is possible that other receptors mediate the entry of SARS-CoV-2 into host cells, such as CD147 [6]. After attachment, the human transmembrane protease serine 2 (TMPRSS2) cleaves and activates the spike protein [7] in an event that allows SARS-CoV-2 to enter the cells by endocytosis or direct fusion of the viral envelope with the host membrane [8,9].

Once inside the cell, the infecting RNA acts as a messenger RNA (mRNA), which is then translated by host ribosomes to produce the viral replicative enzymes, which generate new RNA genomes and the mRNAs for the synthesis of the components necessary to assemble the new viral particles. SARS-CoV-2 replication is a complex process that involves RNA synthesis, proofreading and capping. Similar to other viruses, this process is likely to actively involve many host proteins, like DDX helicases, which are exploited by the virus for more efficient replication [10-12]. Understanding the molecular mechanisms that guide the replication of this coronavirus is essential in order to develop therapeutic tools to neutralize SARS-CoV-2. Here, we review structural information, mostly obtained through homology modeling based on the available structures for other coronaviruses, on the main protein actors of SARS-CoV-2 RNA replication and transcription.

\section{Organization of SARS-CoV-2 Genome}

Like other coronaviruses, SARS-CoV-2 has a positive-sense single-stranded genomic RNA, approximately $30 \mathrm{~kb}$ in length [13], which is among the largest known RNA genomes.

The genomic RNA (gRNA) has a 5'-cap and a 3'-poly(A) tail and can act as an mRNA for immediate translation of the viral polyproteins. In addition, both $5^{\prime}$ - and $3^{\prime}$-ends of the gRNA present a highly structured untranslated region (UTR) that plays an important role in the regulation of RNA replication and transcription. Seven stem-loop structures are present at the $5^{\prime}$-UTR, while a stem-loop and a pseudoknot are present at the $3^{\prime}$-UTR. These two latter structures are mutually exclusive, since their sequences overlap. It is hypothesized that the alternate formation of either the pseudoknot or the stem-loop play some role in the transcriptional regulation [14]. The SARS-CoV-2 genome contains 14 open reading frames (ORFs), preceded by transcriptional regulatory sequences (TRSs). The two main transcriptional units, ORF1a and ORF1ab, encode replicase polyprotein 1a (PP1a) and polyprotein $1 \mathrm{ab}$ (PP1ab), respectively (Figure 1). The largest polyprotein PP1ab embeds non-structural proteins (Nsp1-16), which form the complex replicase machinery. This includes enzyme activities that are rare or absent in other families of positive-stranded (+) RNA viruses [15]. At the $3^{\prime}$ end, the viral genome encodes four structural proteins (spike, envelope, membrane, nucleocapsid), which are components of the mature virus and play a crucial role in viral structure integrity, or as in the case of the spike protein, for viral entry into the host [4-6]. Interspersed among the structural genes, the $3^{\prime}$ end of the genome also contains nine putative ORFs for accessory factors [16] (Figure 1). The structural and accessory proteins are translated from a set of nested sub-genomic (g) RNAs. all terminating with the $3^{\prime}$-end of the full-length gRNA. The generation of these sgRNAs starting from negative-sense RNA intermediates is regulated by the TRSs. During minus-strand RNA synthesis, the viral RNA polymerase pauses at each TRS sequence. The pause can be resolved either by continuing the synthesis through the TRS into the adjacent gene, or it can lead to the termination of transcription with the generation of a sgRNA. The exact molecular mechanisms that determine either outcome are yet to be fully clarified, but they likely involve long-range RNA-RNA interactions between complementary sequences $[17,18]$. 


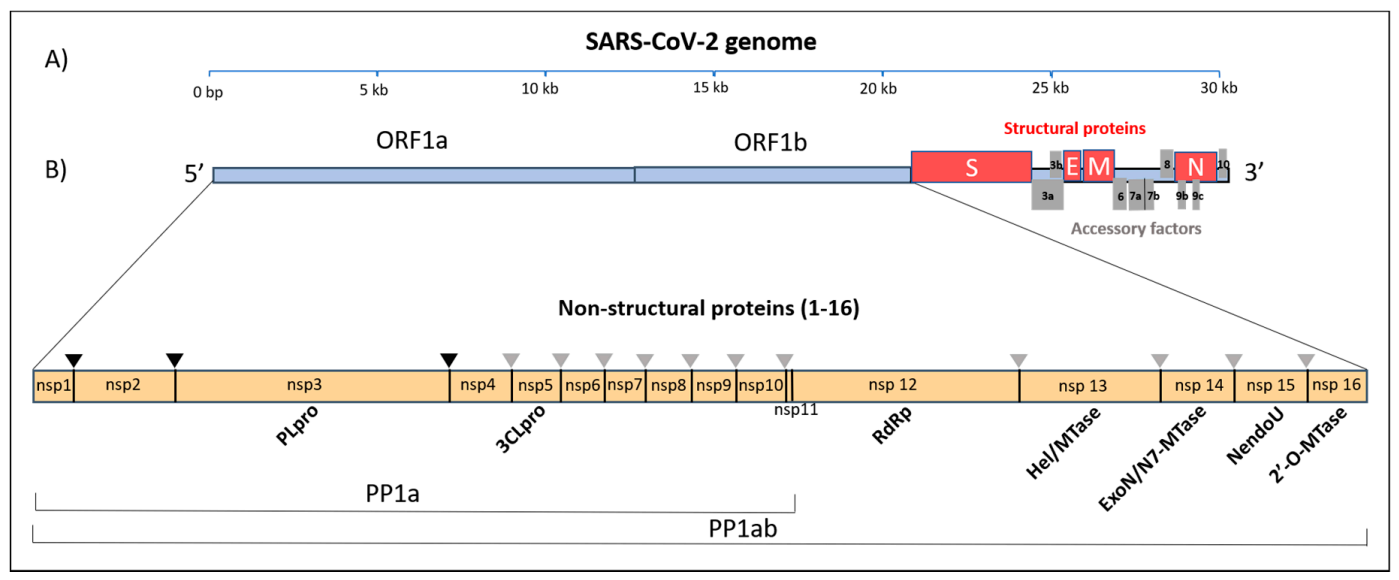

Figure 1. SARS-CoV-2 19 polycistronic genome. (A) Genome of SARS-COV-2 organized in individual ORFs. (B) Polyprotein 1ab (PP1ab) embeds 16 non-structural proteins (Nsps); the black and grey triangles indicate the cleavage sites of the protease PLpro and 3CLpro, respectively. Names of confirmed and putative functional domains in the Nsps are also indicated.

\section{A Structural View at SARS-CoV-2 RNA Replicatory Machinery}

\subsection{RNA Machinery as a Whole: Nsp Interaction Pattern}

Coronavirus RNA synthesis is performed by the replication-transcription complex (RTC), associated with a complex vesicular network [14]. Such membranous structures comprise convoluted membranes (CVs) and double-membrane vesicles (DMVs), originating from the endoplasmic reticulum. These different membranous elements correlate with a precise spatial distribution of the different components of the RTC. The viral replication machinery is anchored to the CVs, thanks to the transmembrane proteins Nsp3, Nsp4 and Nsp6, while the dsRNA originating from the replication-transcription process is mainly contained within the DMVs. This suggests that these latter structures act as a protective environment to avoid detection of dsRNA by innate immunity sensors, and subsequent degradation [19].

The viral RNA replication machinery of SARS-CoV-2 involves an array of functional proteins from the N- to C-termini of the polyprotein, PP1ab (Figure 1). These include the essential RNA-dependent RNA polymerase (RdRp, Nsp12) [20], the zinc-binding helicase (HEL, Nsp13) [21] and a number of other enzymatic functions related to viral RNA modification, such as mRNA capping (Nsp14, Nsp16), RNA proofreading (Nsp14) [22-24], and uridylate-specific endoribonuclease activity (NendoU, Nsp15), which has been shown to counteract double strand RNA sensing [25-27]. The activity of these enzymes is further regulated by the association with other non-structural proteins (Nsp7-Nsp10) that are likely necessary to achieve all of the replication and transcription processes [28-30]. As observed for other nidoviruses, all of these protein subunits likely associate in a replication transcription enzyme complex anchored to membranes derived from the host cell ER [19,31], which drives the synthesis of new genome molecules and also sub-genomic (sg) messenger RNAs (mRNAs) [32]. Table 1 reports all structural information hitherto available for the main non-structural proteins involved in SARS-CoV-2 RNA replication and its homologs, together with their proposed functions.

In addition to these main RNA replication functions, other activities are important to enhance the efficiency of the whole machinery. Suppression of host gene expression and blockage of innate immune responses in infected cells have been attributed to Nsp1, which is considered a major CoV virulence factor [33,34]. Also, the primary role of the nucleocapsid $\mathrm{N}$ protein is to protect the viral genome by packing it into a helical ribonucleocapsid (RNP) $[35,36]$. Accordingly, the $\mathrm{N}$ protein must tightly bind the RNA, even though it is exposed during viral infection, to make it accessible to the replication machinery [37-40]. Furthermore, through interactions mediated by its $C$ terminus, the $N$ protein interacts with the viral envelope protein $\mathrm{M}$, which is also involved in genome condensation and packaging in the viral particle [41-44]. 
Table 1. Available structural information on putative SARS-CoV-2 RNA replication machinery actors.

\begin{tabular}{|c|c|c|c|c|}
\hline Target & Function & PDB Code [Reference] & Source & Seqid $(\%)$ \\
\hline Nsp7 & Cofactor of Nsp12 & $\begin{array}{c}\text { 1YSY [45]; 2KYS [46]; 2AHM (in complex with } \\
\text { Nsp8) [47]; 6NUR (complex with Nsp8 } \\
\text { e Nsp12) [48] }\end{array}$ & SARS-CoV & 98.8 \\
\hline Nsp8 & Cofactor of Nsp12 & $\begin{array}{l}\text { 2AHM (complex with Nsp7) [47]; 6NUR } \\
\text { (complex with Nsp7 e Nsp12) and 6NUS } \\
\text { (complex with Nsp12) [48] }\end{array}$ & SARS-CoV & 97.5 \\
\hline Nsp9 & RNA binding protein & 6W4B, 6W9Q, 6WC1 [49]; 1QZ8 [50]; 1UW7 [51] & $\begin{array}{l}\text { SARS-CoV-2 } \\
\text { SARS-CoV }\end{array}$ & $\begin{array}{l}100 \\
97.4\end{array}$ \\
\hline Nsp10 & $\begin{array}{l}\text { Cofactor of Nsp16 } \\
\text { and Nsp14 }\end{array}$ & $\begin{array}{l}\text { 6W61, 6W75 6W4H (complex with Nsp16); } \\
\text { 2XYR, 2XYV, 2XYQ (complex with Nsp16) [52]; } \\
\text { 3R24 (complex with Nsp16) [53]; 5NFY } \\
\text { (complex with Nsp14) [54]; 5C8S, 5C8T, 5C8U } \\
\text { (complex with Nsp14) [55]; 2GA6 [56] }\end{array}$ & $\begin{array}{l}\text { SARS-CoV-2 } \\
\text { SARS-CoV }\end{array}$ & $\begin{array}{l}100 \\
98.5\end{array}$ \\
\hline Nsp12 & $\begin{array}{l}\text { RNA-directed } \\
\text { RNA polymerase }\end{array}$ & $\begin{array}{l}\text { 6M71 and 7BTF (in complex with Nsp7 and } \\
\text { Nsp8 [57];7BV1 (complex with Nsp7 and Nsp8) } \\
\text { and 7BV2 (complex with Nsp7 and Nsp8, RNA } \\
\text { template/primer and Remdesivir, [58];6NUS } \\
\text { (complex with Nsp8) and 6NUR (complex with } \\
\text { Nsp7 and Nsp8) [48] }\end{array}$ & $\begin{array}{l}\text { SARS-CoV-2 } \\
\text { SARS-CoV }\end{array}$ & $\begin{array}{l}100 \\
96.4\end{array}$ \\
\hline Nsp13 & $\begin{array}{c}\text { Helicase, } \\
5^{\prime} \text { triphosphatase }\end{array}$ & 6JYT [59]; 5WWP [60] & $\begin{array}{l}\text { SARS-CoV } \\
\text { MERS-CoV }\end{array}$ & $\begin{array}{l}99.8 \\
72.2\end{array}$ \\
\hline Nsp14 & $\begin{array}{l}3^{\prime}-5^{\prime} \text { exoribonuclease, } \\
\text { ExoN; Guanine-N7 } \\
\text { methyltransferase, } \\
\text { N7 MTase }\end{array}$ & $\begin{array}{l}\text { 5C8S, 5C8U, 5C8T (complex with Nsp10) [55]; } \\
\text { 5NFY (complex with Nsp10) [54] }\end{array}$ & SARS-CoV & $\begin{array}{l}95.1 \\
94.9\end{array}$ \\
\hline Nsp15 & $\begin{array}{l}\text { NendoU, } \\
\text { Uridylate-specific } \\
\text { endoribonuclease }\end{array}$ & $\begin{array}{l}\text { 6W01, 6VWW [61]; } \\
\text { 2H85 [62]; 2RHB [63] }\end{array}$ & $\begin{array}{l}\text { SARS-CoV-2 } \\
\text { SARS-CoV }\end{array}$ & $\begin{array}{l}100 \\
88.0\end{array}$ \\
\hline Nsp16 & $\begin{array}{l}\text { 2'-O-ribose } \\
\text { methyltransferase }\end{array}$ & $\begin{array}{l}\text { 6W4H, 6W75, 6W61 (complex with Nsp10); } \\
\text { 2XYR, 2XYV, 2XYQ (complex with Nsp10) [52]; } \\
\text { 3R24 (complex with Nsp10) [53]; } \\
\text { 5YN5 (complex with Nsp10). }\end{array}$ & $\begin{array}{l}\text { SARS-CoV-2 } \\
\text { SARS-CoV } \\
\text { MERS-CoV }\end{array}$ & $\begin{array}{l}100 \\
93.5 \\
66.1\end{array}$ \\
\hline
\end{tabular}

Data in the literature on possible interactions among the individual actors of the RNA polymerase machinery of SARS-CoV-2 are still limited. However, based on data for highly homologous proteins from either SARS-CoV (sequence identity $>88 \%$ ) or mouse hepatitis virus (MHV) (sequence identity $>40 \%$, Table S1), we reconstituted the likely pattern of interactions among the Nsp proteins constituting the RNA replication/transcription machinery (Figure 2). Among these, we predict that Nsp12 and Nsp8 play a central role in the assembly of the entire RNA polymerase replicative machinery. Nsp12, a RNA-dependent RNA polymerase is the key enzyme mediating the synthesis of all viral RNA molecules [64]. Biochemical studies have proved that Nsp12 from SARS-CoV exhibits low processive RNA synthesis in vitro, as it requires the presence of Nsp7 and Nsp8 to bind nucleic acid and perform efficient RNA synthesis $[28,29]$. The direct association between Nsp8 and Nsp12 has been reported in several coronaviruses and it is a feature that is likely shared by most, if not all, coronaviruses $[65,66]$. We also predict that Nsp12 of SARS-CoV-2 is able to interact with Nsp13 helicase based on studies of the highly homologous Nsp12 and Nsp13 from SARS-CoV (96.4 and 99.8\% sequence identity, respectively). Indeed, Nsp12 of SARS-CoV can enhance the helicase activity of Nsp13 through a direct protein-protein interaction [59]. The positive regulation of Nsp13 by Nsp12 is an important event in viral replication. Indeed, mutation of specific conserved residues of Nsp13 can either negatively impact or block replication of the arterivirus, equine arteritis virus (EAV) [67,68]. Finally, similar to SARS-CoV, Nsp12 is most likely able to associate with Nsp14 [29], Nsp5 and Nsp9 [69] (Figure 2).

Nsp8 and Nsp7/Nsp8 complex can also bind and enhance the endoribonuclease NendoU activity of MERS-CoV Nsp15 in vitro [70]. This result agrees with previous evidence showing that Nsp15 from MHV colocalizes and interacts in vivo with Nsp8 and Nsp12 [71]. However, whether Nsp15 belongs to the RNA replication machinery is still an open question. Finally, Nsp8 deletion or disruption of the protease cleavage site between Nsp7 to Nsp9, which is necessary to correctly process the 
corresponding proteins, both result in impaired RNA synthesis and a lethal phenotype in MHV [72]. Altogether, these findings identify the Nsp12-Nsp8 complex as a key hub for the viral replication machinery (Figure 2).

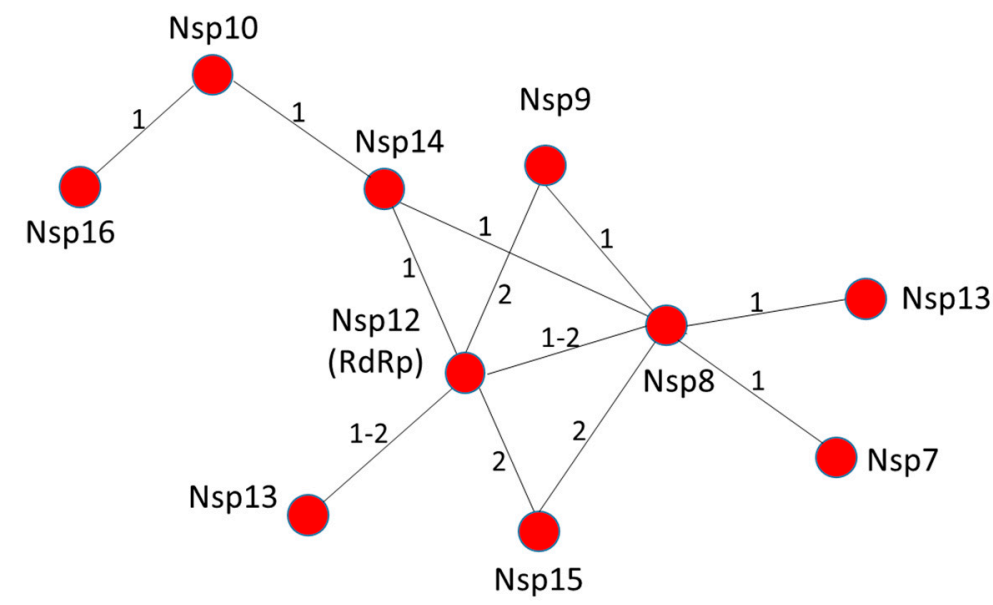

Figure 2. Nsp12 and Nsp8 are a hub for interactions among actors of the RNA replication machinery. Predicted pattern of interactions based on the available literature data. The numbers 1 and 2 on the strings refer to SARS-CoV and MHV, respectively.

\subsection{RNA Polymerization Requires Nsp12 and Cofactors Nsp7, Nsp8}

SARS-CoV-2 RNA polymerization relies on the main polymerase, Nsp12, also denoted as RNA-dependent RNA polymerase, RdRp. Nsp12 is a large enzyme (932 residues) characterized by two conserved domains: the NiRAN and the polymerase domains (Figure 3A). The structure of SARS-CoV Nsp12 bound to the Nsp7 and Nsp8 cofactors has recently been determined using cryo-EM [48]. During the preparation of this manuscript, the structure of SARS-CoV-2 Nsp12 has also been reported [57]. Consistent with the high sequence identity between the Nsp12 form SARS-CoV and SARS-CoV-2 (94\%), the two structures are nearly identical, as indicated by their root mean square deviation of $0.8 \AA$ for 1078 $\mathrm{C} \alpha$ atoms [57]. In both structures, Nsp12 is complexed with the two co-factors Nsp7 and Nsp8 (Figure 3B). The observed interactions in the complex structure Nsp12-Nsp8-Nsp7 are compatible with a previous work addressing the impact of residues of Nsp7 and Nsp8 on their interactions with Nsp12 [29].

The N-terminal domain of Nsp12, which has been shown to be essential for viral growth in both equine arteritis virus (EAV) and SARS-CoV [73], is conserved in all nidoviruses endowed with nucleotidylation activity. Therefore, it is named NiRAN from nidovirus RdRp-associated nucleotidyltransferase (Figure 3A,B) [73]. The structure of the NiRAN domain was only partially described in the structure of SARS-CoV Nsp12, whereas it is fully complete in the last released structure of the SARS-CoV-2 Nsp12-Nsp7-Nsp8 complex [57]. Overall, the form of this domain is characterized by an $\alpha+\beta$ fold composed of eight $\alpha$ helices and a five stranded $\beta$-sheet (Figure 3B). In addition, an N-terminal $\beta$-hairpin (residues 29-50) interacts with the palm subdomain of the RdRp domain (Figure 3B) [57]. This information provides structural tools to understand the functional role of the NiRAN domain in Nsp12. Indeed, although the exact role of this domain is not fully clear, structural similarity analyses using DALI suggest that the NiRAN domain of SARS-CoV-2 Nsp12 displays structural features of kinase-like folds [48]. Indeed, using DALI we identified two kinases as the most similar structures, the serine/threonine kinase PRP4 homolog (PDB code 6PJJ, DALI Z = 10.5, RMSD $=2.8 \AA$, seqid $15 \%$ ) and tyrosine-protein kinase JAK1 (PDB code 6C7Y, DALI Z = 10, RMSD = $2.8 \AA$, seqid 11\%) [74]. Given the importance of the NiRAN domain in viral growth [73], this structural observation suggests a further tool for drug development using kinase inhibitors. 
A)
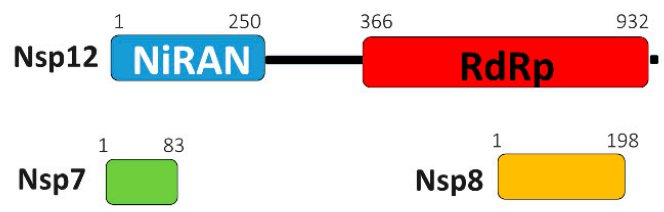

B)

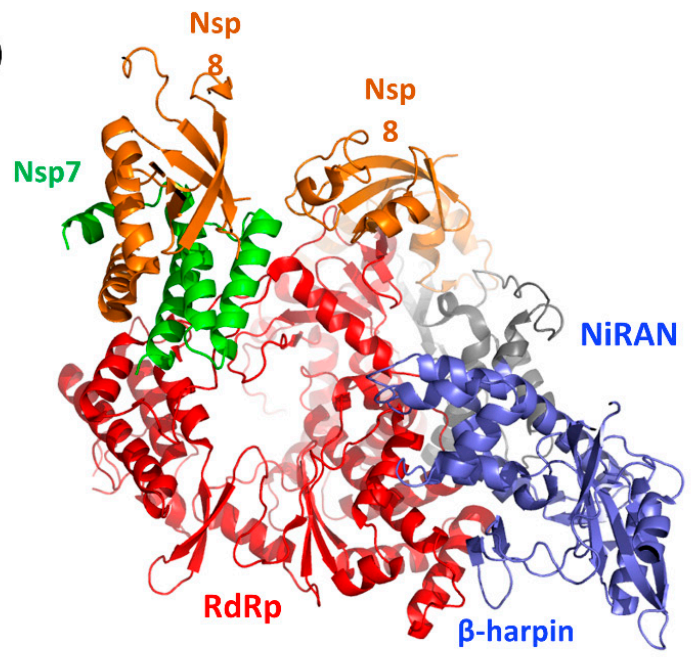

D)

C)

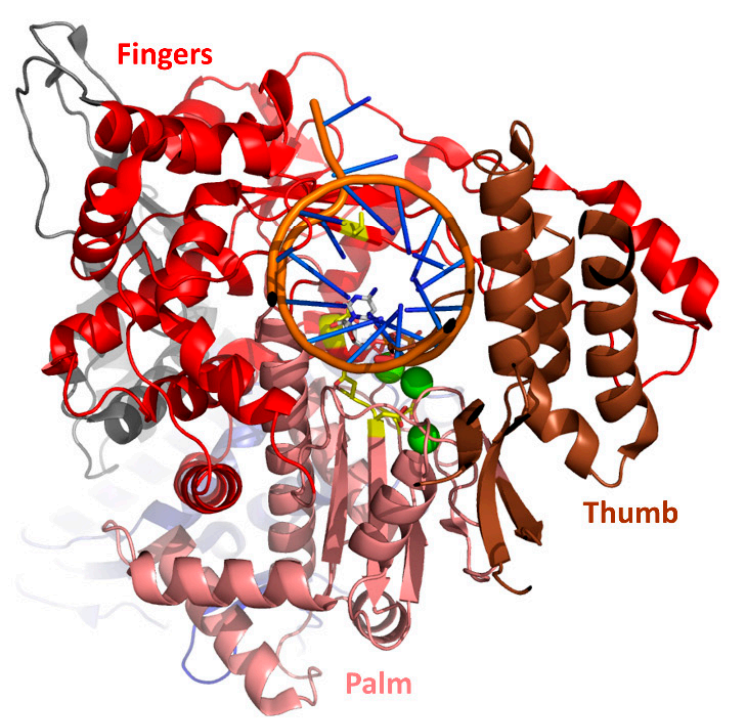

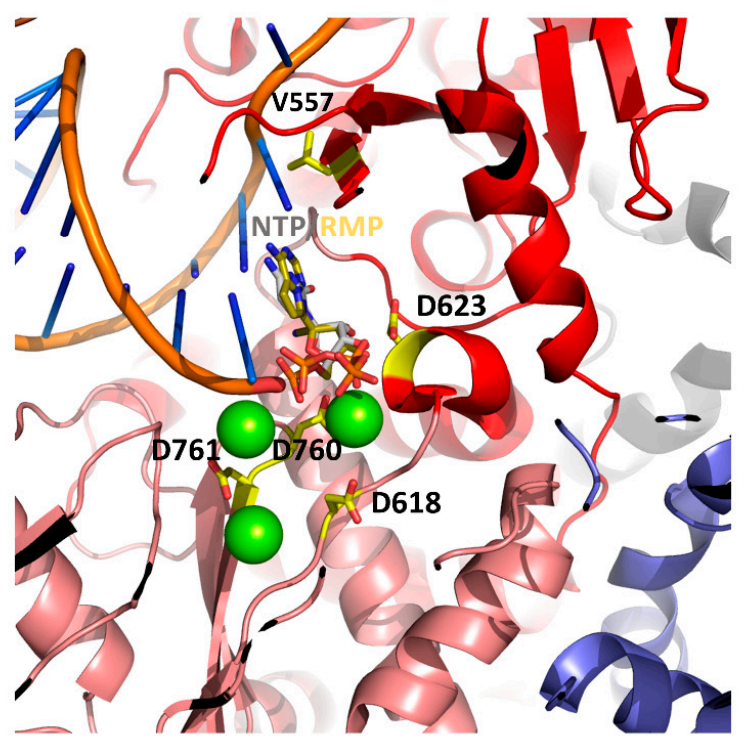

Figure 3. SARS-CoV-2 Nsp12-Nsp7-8 complex. (A) Domain organization of Nsp12, with its Nsp7 and Nsp8 cofactors, according to Pfam. (B) Cartoon representation of Nsp12 SARS-CoV-2 bound to Nsp7 and Nsp8 cofactors (PDB code 7BTF). (C) Model of SARS-CoV-2 elongation complex. The positions of the RNA template/primer and of the divalent cations were obtained from the structural alignment of the complex in panel A with the elongation complex from SARS-CoV-2 (PDB code 7BV2), while the position of NTP was obtained from the alignment with the polymerase of norovirus (PDB code 3H5Y). The three subdomains of the polymerase domain, finger (residues 366-581 and 621-679), palm (residues 582-620 and 680-815), and the thumb (residues 816-920) are shown in red, salmon and brown, respectively. (D) A zoom of the catalytic site showing the position of the incoming NTP, Remdesivir monophosphate (RMP) (in stick) and divalent cations (as green spheres). The conserved Asp residues that play a key role in the NTP and $\mathrm{Mg}^{2+}$ binding and Val557 (involved in Remdesivir resistance) are shown as yellow sticks.

The RNA polymerase C-terminal domain of Nsp12 (residues 366-920) from SARS-CoV-2 adopts a conformation that has been described as a cupped right hand, constituted of finger, palm and thumb subdomains $[48,57]$ (Figure 3C). Biochemical and structural studies of polymerases from other viruses, e.g., poliovirus and foot-and-mouth disease virus, have defined the catalytic cycle of the RNA polymerase as a multi-step process composed of successive steps $[75,76]$. Catalytic residues 
can be identified in SARS-CoV-2, upon alignment with poliovirus RNA polymerase, whose catalytic residues are known, with the two aspartic acids Asp618 and Asp760 (Supplementary Materials, Figure S1). Consistently, the D760A mutant of SARS-CoV Nsp12 is unable to synthetize RNA [29]. Together with these two aspartic acids, Asp623 and Asp761 are also involved in the recognition of the NTP triphosphate and divalent cations, respectively $[48,57]$. The recent crystal structure of SARS-CoV-2 Nsp12-Nsp7-Nsp8 has confirmed that both Asp760 and Asp761 are involved in the coordination of the two important magnesium ions at the catalytic center (Figure 3D). Importantly, a key initiation step is the addition of the first one or two nucleoside triphosphates (NTP) onto a primer, to form a stable and processive elongation complex $[75,76]$. The structure of the elongation complex of SARS-CoV-2 contains 14 bases in the template strand and 11 bases in the primer strand. This double-stranded RNA helix contacts all of the three Nsp12 subdomains (finger, palm, thumb, Figure 3C). Most of protein-RNA interactions are mediated with the RNA phosphate-ribose backbones, with many interactions directly to 2'-OH groups, thus providing a basis to distinguish RNA from DNA [58]. Notably, the position of the RNA primer is nearly superimposable to that obtained for the well characterized poliovirus $[75,77]$ (Figure 3D, Figure S1). Also, residues involved in RNA binding and composing the catalytic active site are highly conserved (Figure 3, Figure S1), thus suggesting a similar mechanism of RNA replication. It is interesting to note that apo and complexed Nsp12 are almost identical, with an RMSD of $0.5 \AA$, thus suggesting that SARS-CoV-2 Nsp12 does not require a conformational switch upon ligand binding. This hypothesis agrees well with the high processivity of viral RNA polymerases [76] since no extra energy is required to switch the enzyme conformation towards activation.

Although sequence identity of Nsp12 with RdRP from the Ebola virus (EBOV) is quite poor (16\%), structural analysis indicates the conservation of the polymerase active site. Remdesivir, the nucleotide inhibitor of the EBOV RdRP has been recognized as a promising antiviral drug against a wide array of RNA viruses including filoviruses, arenaviruses, paramyxoviruses, and other coronaviruses with divergent RdRp, such as SARS-CoV, MERS-CoV, bat CoV, and the new SARS-CoV-2 strains [78-83] in cultured cells, mice and nonhuman primate models $[78,84,85]$. Remdesivir is a prodrug, which is metabolized into its active form (GS-441524), which causes a decrease in viral RNA production [78] (Figure 4). The compound has a 1'-cyano group, which provides potency and selectivity toward viral RNA polymerases, and a monophosphate promoiety to enhance intracellular metabolism into the active triphosphate metabolite [86] (Figure 4). Remdesivir triphosphate is able to inhibit EBOV replication with half maximal effective concentrations (EC50) in the sub-micromolar range [78] by blocking viral RNA synthesis [78]. The mechanism of inhibition is a delayed chain termination of nascent viral RNA, as described for several viral RdRP, including EBOV, MERS, Nipah (NIV) and respiratory syncytial virus RSV [78,87-89]. In all cases, Remdesivir triphosphate inhibits transcription by competing with the incorporation of natural NTP counterparts [87,89]. This finding has been recently corroborated for SARS-CoV-2 by the determination of the structure of Nsp12-Nsp7-Nsp8 in complex with RNA template/primer and Remdesivir [58] (Table 1). This structure has shown that Remdesivir monophosphate (RMP) is covalently incorporated at the $3^{\prime}$ end of the primer strand [58]. As shown in Figure 3D, this position fully overlaps with the +1 position of a natural NTP. Additionally, it was previously shown for MHV and SARS-CoV [79] that a mutation of a conserved valine residue of Nsp12, corresponding to V557L in SARS-CoV-2, confers low-level resistance to Remdesivir; it impairs fitness and attenuates virulence. This mutation is located in proximity to the NTP binding site of Nsp12 [58] (Figure 3D). 


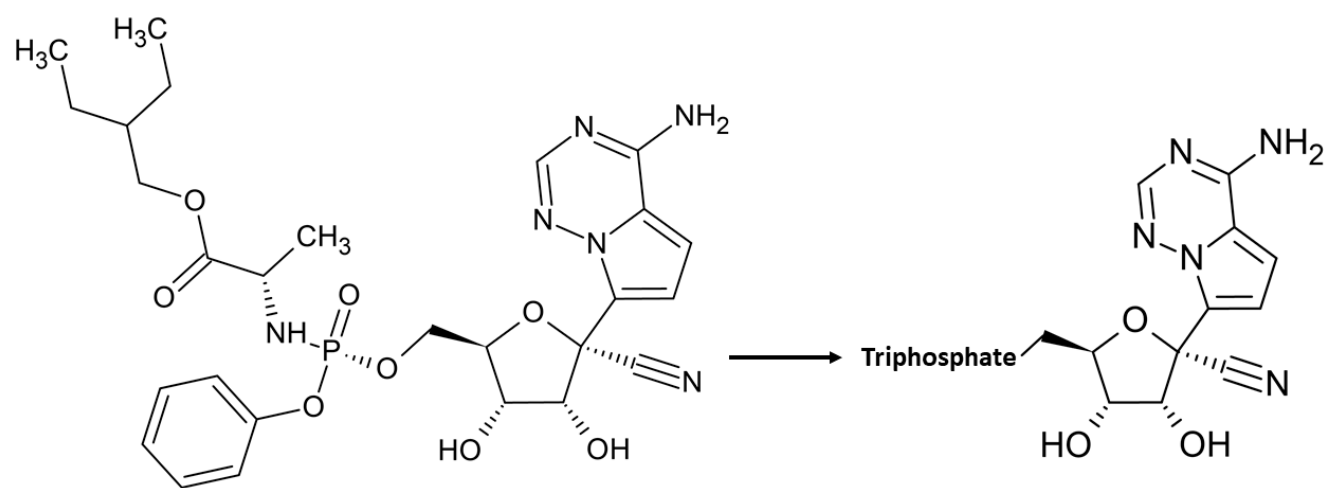

Figure 4. Chemical structure of Remdesivir (GS-5734) and its pharmacologically active nucleoside triphosphate NTP.

Significantly, a recent study revealed that Remdesivir is effective in the control of SARS-CoV-2 in vitro [81]. From the clinical point of view, Remdesivir is being used in a small number of SARS-CoV-2 positive patients for "compassionate use" based on the patients' worsening clinical status. One of the first cases in the USA is responding well to the nucleoside analogue with an immediate improvement after intravenous injection [90]. Nevertheless, it is not yet approved for general use and clinical trials are currently underway to determine its safety and efficacy [91]. Structurally-based improvements of this drug may constitute a valid tool to enhance its specificity and efficiency against coronaviruses.

\subsection{RNA Proofreading and mRNA Capping through the Bifunctional Protein Nsp14 and Cofactor Nsp10}

Nsp14 of SARS-CoV-2 contains two domains with different functions, as identified by the PFAM database (Figure 5A). The $\mathrm{N}$ terminal domain $(\mathrm{ExON})$ is endowed with exoribonuclease activity and includes three conserved motifs: motif I (DE), II (E) and III (D). Due to this feature, Nsp14 is included as a "DEED outlier" into the superfamily of DEDD exonucleases [55,92], which embrace enzymes with proofreading activity $[92,93]$. In line with this observation, ExoN knockout mutants of SARS-CoV and murine hepatitis virus (MHV) were shown to accumulate a high number of mutations [94,95]. The carboxy-terminal part of Nsp14, containing (N7 guanine)-methyl transferase activity, is involved in the viral mRNA cap synthesis. The RNA final cap has several important biological roles in viruses as it is critical for the stability of mRNAs, for their translation and to evade the host immune response. Indeed, uncapped RNA molecules are degraded in cytoplasmic granular compartments and may be detected as "non-self" by the host, therefore triggering innate immune responses [96,97].

A homology model of the complex between Nsp14 and Nsp10 of SARS-CoV-2 is reported in Figure $5 \mathrm{~B}$, based on the structure of homologous proteins of SARS-CoV [54,55] (Table S1). In this complex, the co-factor Nsp10, composed of a helical domain and an irregular $\beta$-sheet region followed by a loop region at its C-terminus, forms multiple interactions with the ExoN domain of Nsp14, likely stabilizing it. Consistent with this, SAXS experiments of Nsp14 from SARS-CoV in the absence of Nsp10 show large conformational changes in the $\mathrm{N}$ terminus of Nsp14, which affect the overall shape of the exonuclease fold [54]. Importantly, the interaction with Nsp10 strongly affects the nucleolytic activity of SARS-CoV Nsp14, which is enhanced up to 35-fold [98]. 
A)

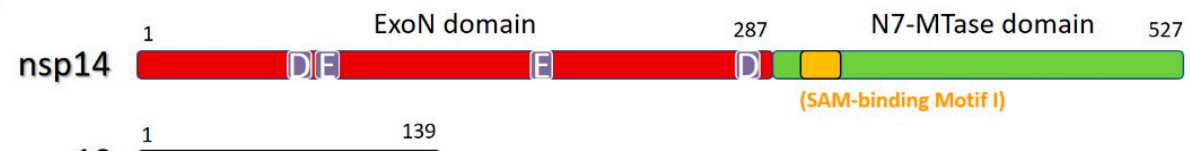

B)

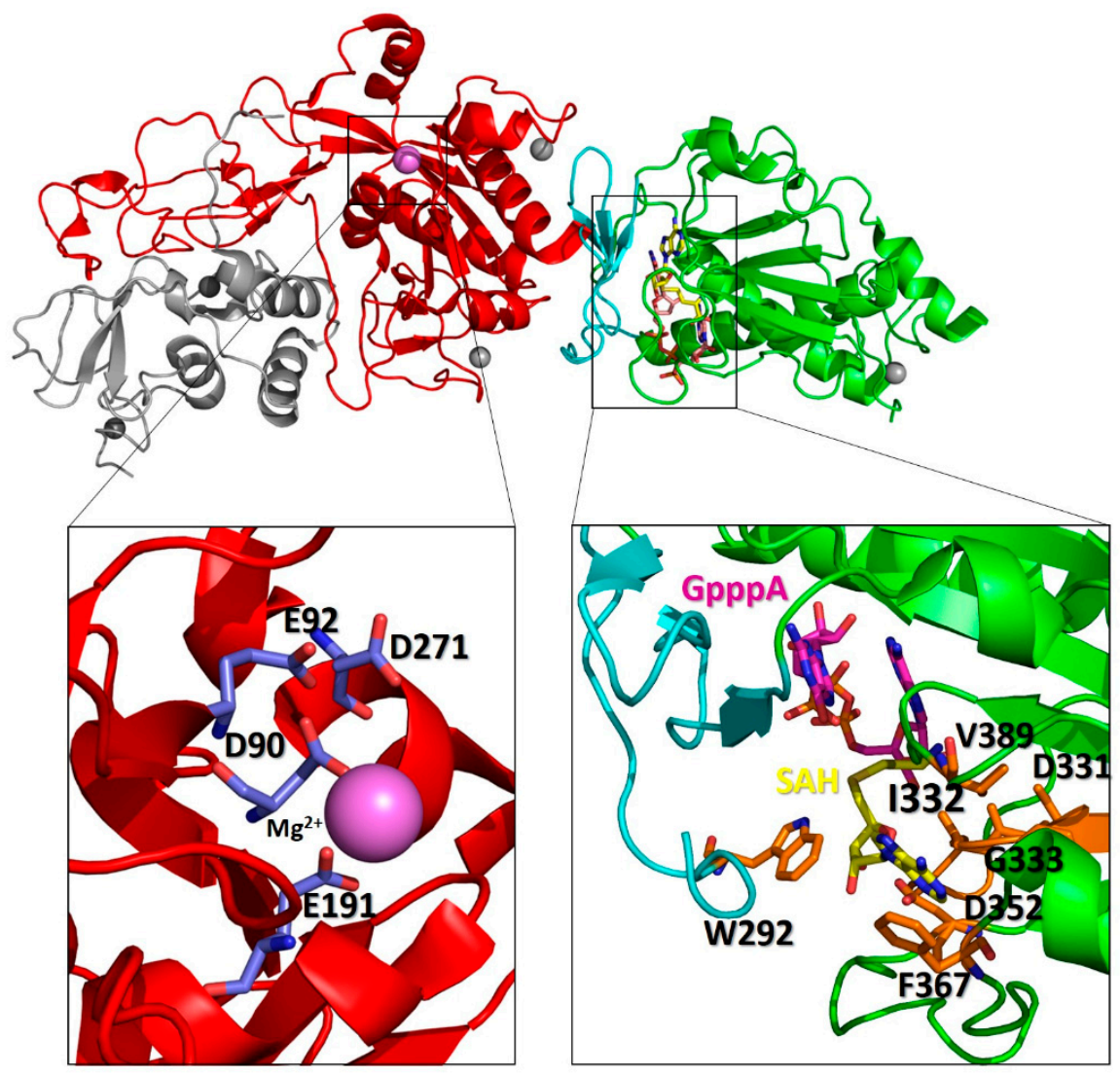

Figure 5. Homology model of SARS-CoV-2 Nsp14-Nsp10 complex. (A) Domain organization of Nsp14 and Nsp10; (B) Cartoon representation of the homology model of the complex, computed with MODELLER using the structure of its homolog from SARS-CoV as a template (PDB code 5C8S, covered region 1-131 in Nsp10 and 1-525 in Nsp14). Zinc atoms are shown as grey and a $\mathrm{Mg}^{2+}$ ion as magenta spheres. Zooms of the catalytic sites are shown in the insets. Catalytic residues of the ExoN domain (left inset) are shown as blue sticks, those of the N7-MTase domain (right inset) are shown as orange sticks; the cap-precursor GpppA (pink), a SAH (demethylated form of SAM) ligand (yellow) and the SAM-binding motif residues (orange) are also represented as sticks.

The ExoN domain of Nsp14 presents an $\alpha / \beta$ fold as do the other members of the DEDD exonuclease superfamily [99]. It is composed of a central twisted $\beta$-sheet formed by five $\beta$-strands. These, are flanked by $\alpha$-helices, with the exception of the strand $\beta 3$ (Figure 5B) [54,55]. Based on its structural alignment with SARS-CoV, the catalytic residues of the ExoN domain of SARS-CoV-2 Nsp14 include the DEED residues Asp90, Glu92, Glu191, Asp272 (Figure 5). A structural alignment using DALI shows that this domain is structurally similar to E. coli RNase T and to RNase AS from M. tuberculosis, two exonucleases involved in RNA maturation through 5' processing $[100,101]$. Similar to these exonucleases, alanine substitution of the four catalytic residues of ExoN, which coordinate $\mathrm{Mgg}^{2+}$ ion (Figure 5B), results in a significant reduction of the viral RNA synthesis [94,100-103]. Altogether, these data suggest that like Nsp12, Nsp14 has a crucial role in SARS-CoV-2 replication through its ExoN domain, as it is involved in maintaining the integrity of the SARS-CoV-2 RNA genome, preventing and repairing mutations [95,104]. In this context, susceptibility of EBOV to Remdesivir also involves the proofreading exoribonuclease, Nsp14 [79]. For EBOV RNA polymerase, the incorporation of the 
nucleotide analogue at position $\mathrm{n}$ causes inhibition of RNA synthesis predominantly at position $\mathrm{n}+$ $5[88,89]$ whereas in the case of MERS, arrest of RNA synthesis occurs at position $n+3$, with these three nucleotides likely protecting the inhibitor from excision by the viral $3^{\prime}-5^{\prime}$ exonuclease activity [89]. In both cases, delayed chain-termination could be due to inhibitor-induced structural changes of the newly synthesized double stranded RNA $[105,106]$. Importantly, a mutant lacking ExoN was significantly more sensitive to Remdesivir, suggesting that this nucleoside analogue, once incorporated into viral RNA, can be removed by the exoribonuclease activity of Nsp14 during proofreading [79,107]. Therefore, nucleoside analogues that effectively inhibit viral RNA replication must either evade detection by the exonuclease or outcompete exonuclease activity [108]. In this case, chemical modifications of the nucleoside analogues to skip recognition by Nsp14, or simultaneous inhibition of Nsp12 and Nsp14, would provide a synergistic action in the inhibition of RNA synthesis and be a powerful strategy against SARS-CoV-2.

A flexible hinge region consisting of a loop and three strands (shown as cyan in Figure 5B) separates the ExoN domain from the N7-MTase domain of Nsp14 and is highly conserved across CoVs. This region allows lateral and rotational movements of the two domains to coordinate the two different enzymatic activities of Nsp14 (Figure 5B) [92]. Following this hinge region, the N7-MTase domain is an (N7 guanine)-methyl transferase involved in RNA capping, which operates by demethylating its co-enzyme S-adenosyl methionine (SAM). This domain shows unique structural features as it displays an atypical fold, different from the canonical Rossmann fold of the virus RNA MTase [54,109]. In addition, it does not belong to any of the classes of SAM-dependent MTases [110-112]. Indeed, a typical Rossmann fold embeds a central core of $\beta$-sheets composed of seven parallel $\beta$-strands with at least three a-helices on each side [109]. Differently, the $\beta$ sheet of the N7-MTase domain of Nsp14 is formed by five $\beta$-strands instead of seven (Figure 5B). SARS-CoV Nsp14-Nsp10 crystal structure [55], together with alanine scanning mutagenesis [113] and cross-linking experiments, revealed two clusters of residues that are key for the N7-MTase activity (Figure 5B) [113-115]. The first cluster is a canonical SAM-binding motif I (DxGxPxG/A) and includes Asp331, Gly333, Pro335 and Ala337 (Figure 5B), where SAM is the methyl donor in the (N7 guanine)-methyl transferase reaction catalyzed by Nsp14. A second cluster forms a pocket that holds the GTP of the mRNA cap structure in close proximity of the methyl donor SAM (Figure 5B). The binding mode of the functional ligands, the cap-precursor guanosine-P3-adenosine- $-5^{\prime}, 5^{\prime}$-triphosphate (GpppA) and the product of SAM demethylation, S-adenosyl Homocysteine (SAH), occurs with no significant structural changes in the enzyme [55]. These studies have helped to shed light on the mechanism of RNA cap formation, which also involves several other protein actors, as detailed below.

\subsection{SARS-CoV-2 Capping Machinery Involves Nsp13, Nsp14, Nsp16 and the co-Factor Nsp10}

\subsubsection{RNA Cap Synthesis in Coronaviruses}

mRNAs of coronaviruses are protected at their $5^{\prime}$ ends by a cap structure consisting of an N7-methylated GTP molecule linked to the first transcribed nucleotide by a $5^{\prime}-5^{\prime}$ triphosphate bond. Given the importance of RNA capping for mRNA stability and as a mechanism to evade the host immune response, RNA-capping machineries are an attractive target for antiviral-drug design. In coronaviruses, apart from the N7-MTase domain of Nsp14 described above, the cap synthesis

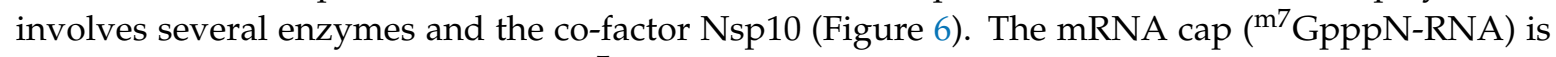
composed of a 7-methylguanosine $\left({ }^{\mathrm{m} 7} \mathrm{G}\right)$ linked to the $5^{\prime}$-nucleoside $(\mathrm{N})$ of the RNA chain through a triphosphate bridge (ppp). The process begins with the hydrolysis of the $5^{\prime} \gamma$-phosphate of the nascent RNA chains (pppN-RNA) by an RNA 5'-triphosphatase, the Nsp13 helicase [21]. Subsequently, a still unidentified GTase transfers a GMP molecule to the $5^{\prime}$-diphosphate of the RNA chains (ppN-RNA), leading to the formation of GpppN-RNA. Then, the cap structure is methylated at the N7 position of the guanosine by the C-terminal N7-MTase domain of Nsp14, forming cap-0 ( ${ }^{\mathrm{m} 7} \mathrm{GpppN}-\mathrm{RNA}$ ), using SAM as a methyl donor. Finally, Nsp16 (SAM)-dependent 2'-o-methyltransferase activity 
promotes the addition of a methyl group on the ribose $2^{\prime}-\mathrm{O}$ position of the first transcribed nucleotide to form cap-1 ( $\left.{ }^{\mathrm{m}} \mathrm{GpppNm}-\mathrm{RNA}\right)$ [52,53] (Figure 6). In the last steps, the cofactor Nsp10 acts as an allosteric activator [52,53].

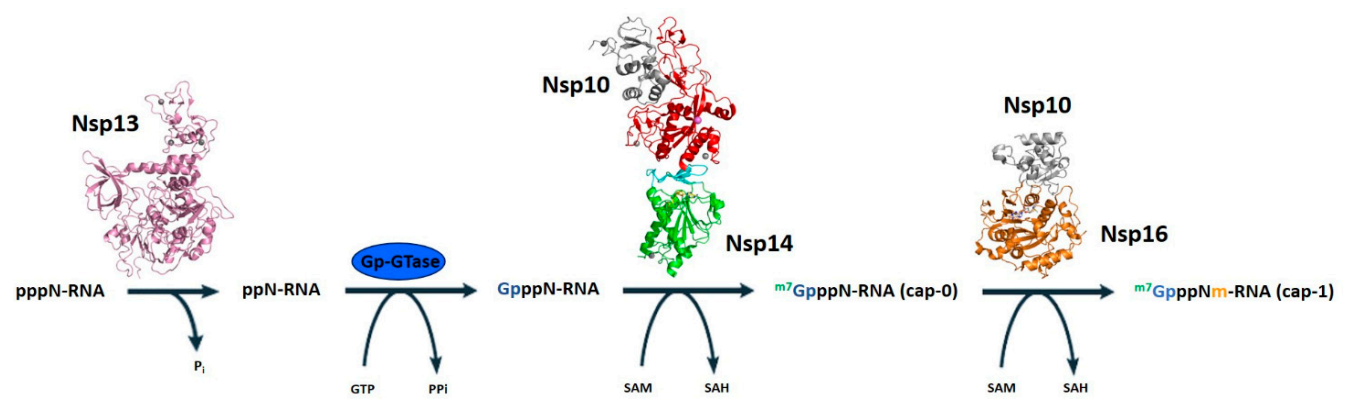

Figure 6. The mRNA cap synthesis process in SARS-CoV-2. The process is performed by the sequential action of four enzymes: Nsp13 (pink), a still unknown GTase, Nsp14 (red) and Nsp16 (orange). The presence of the co-factor Nsp10 (grey) is fundamental for the activity of the last two enzymes.

\subsubsection{Start of mRNA Capping by the Multi-Functional Nsp13 Helicase}

Helicases are versatile NTP-dependent enzymes that are widespread in all kingdoms of life including (+) RNA viruses with genome greater than $7 \mathrm{~kb}$ [116]. They are classified into six superfamilies (SF1 to SF6) and are known to be critically involved in several processes connected to nucleic acid metabolism [116]. Helicases are required for the unwinding of dsDNA and/or dsRNA substrates, for displacing proteins bound to nucleic acid or remodeling DNA or RNA secondary structures and for translocating along double-strand nucleic acid without unwinding [68]. Sequence conservation analysis shows that Nsp13 of SARS-CoV-2 belongs to the SF1 superfamily and shares many structural features with the eukaryotic Upf1 helicase, a key factor in nonsense-mediated mRNA decay in cells [117]. Like other coronaviruses, Nsp13 exhibits multiple enzymatic activities, which include not only the hydrolysis of NTPs required in the capping mechanism (Figure 6), but also unwinding of RNA duplexes with $5^{\prime}-3^{\prime}$ directionality and the RNA 5'-triphosphatase activity $[118,119]$. Additionally, RNA unwinding activity is stimulated by the interaction with the RdRP Nsp12 [120]. Nsp13 is highly conserved in all coronaviruses and is a key enzyme in viral replication [121,122], two observations which make it a promising target for antiviral therapies [68]. In this context, a potent non-competitive inhibitor (SSYA10-001) blocks viral replication by inhibiting the unwinding activity of the helicase Nsp13 [123], not only in SARS-CoV but also for two other coronaviruses, MHV and MERS-CoV [124].

Nsp13 of SARS-CoV-2 shares the same structure as that of SARS-CoV [59], given the extremely high conservation of protein sequences (Table S1), and consists of five domains which fold in a triangular pyramid shape (Figure 7B). A similar organization was observed for MERS helicases [60]. Three domains named $1 \mathrm{~A}$ and $2 \mathrm{~A}$ and the $1 \mathrm{~B}$ domain are arranged to form the triangular base, leaving the remaining two domains, the N-terminal Zinc binding domain (ZBD) and the stalk domain, at the apex of the pyramid (Figure 7B). Mutagenesis and structural alignments demonstrated that the $1 \mathrm{~B}, 1 \mathrm{~A}$ and 2A domains are responsible for NTP activity and nucleic acid binding, whereas other functional information about the structural coordination of these five domains in helicase activity have been deduced through the $\mathrm{H} / \mathrm{D}$ exchange assays. As explained above, the activity of Nsp13 is enhanced by Nsp12 through direct interaction, with the interaction region on Nsp13 mapped on the ZBD domain and the $1 \mathrm{~A}$ domain [59]. Given the high sequence conservation of these two proteins, their association can be considered a common feature across CoV [59]. 
A)

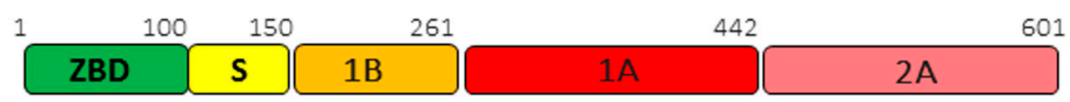

B)

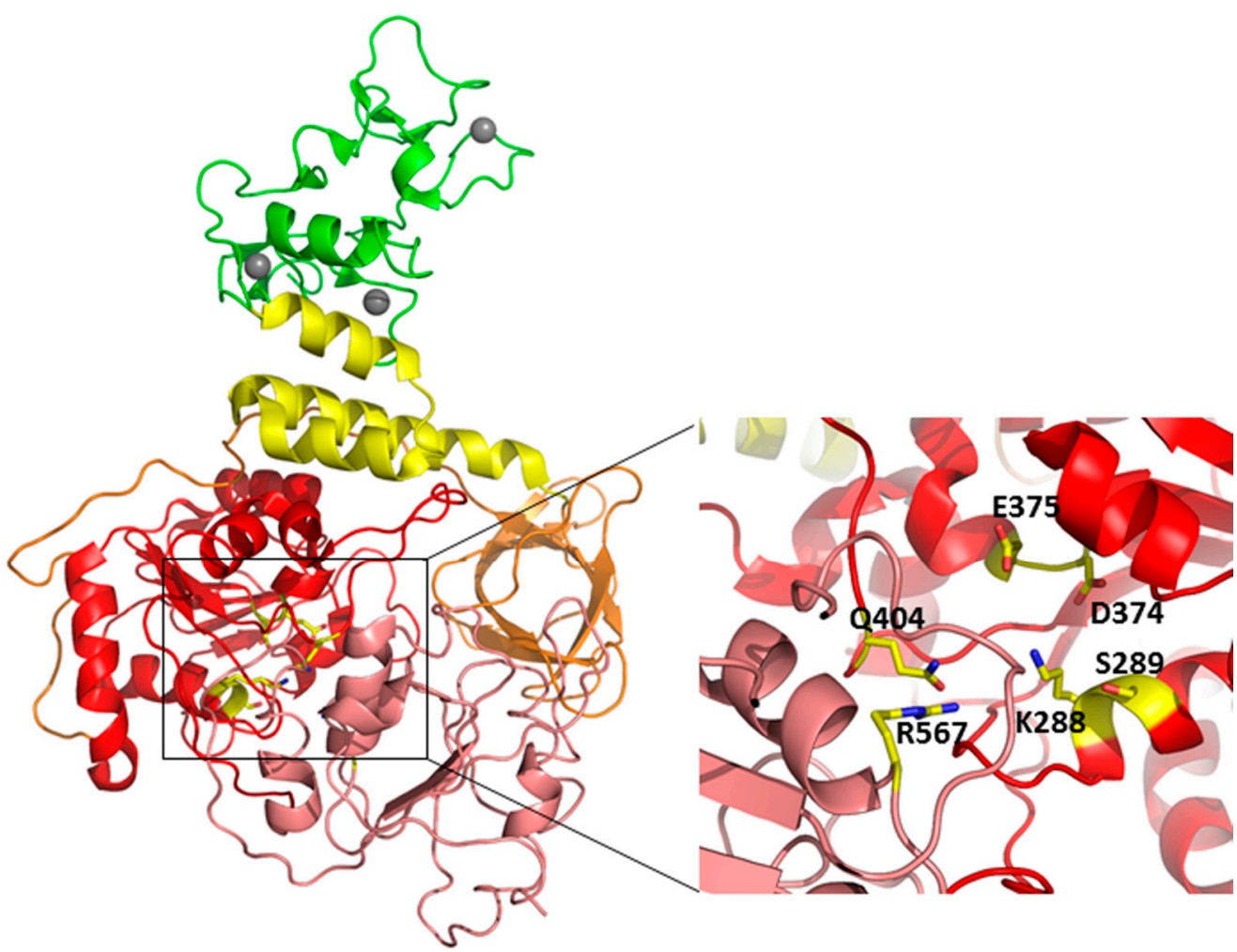

Figure 7. SARS-CoV-2 Nsp13 helicase. (A) Domain organization of SARS-CoV-2 Nsp13. (B) Cartoon representation of the homology model of SARS-CoV-2 Nsp13, obtained using MODELLER based on the crystallographic structure of the SARS-CoV (PDB code 6JYT, covered region 1-596). The colors of the protein domains are indicated in panel A (ZBD-green, stalk-yellow, 1B-orange, 1A-red and 2A-salmon). Three zinc atoms are shown as grey spheres. In the inset, the key conserved residues responsible for NTP hydrolysis are drawn as sticks.

3.4.3. End of mRNA Capping by 2'-o-Methyl Transferase Nsp16 and Nsp10, an Allosteric Activator and a Molecular Connector?

Several X-ray structures of Nsp16 are deposited in the PDB, including those from SARS-CoV, MERS-CoV and more recently of SARS-CoV-2 (Table 1). In all of these structures, Nsp16 is complexed with the cofactor Nsp10 and presents a similar topological organization [53,125]. In particular, Nsp16 possesses the typical fold of the class I MTase family, comprising a seven-stranded $\beta$ sheet flanked by $\alpha$ helices with the characteristic reversed $\beta$ hairpin at the carboxyl end of the sheet ( $\beta 6-\beta 7$ ) (Figure 8) [112]. The catalytic site cleft of Nsp16 contains the conserved K-D-K-E catalytic tetrad, which is peculiar to SAM-dependent 2'-o-methyltranferases. Specifically, the four residues Lys46, Asp130, Lys170 and Glu203 are predicted to be catalytic (Figure 8) [112]. In addition, a conserved SAM-binding pocket is located at the C-terminal end of strands $\beta 1$ and $\beta 2$, as in the case of other SAM-dependent MTases [126] (Figure 8). Two zinc ions were identified as bound to two zinc finger regions and found to be indispensable for the binding of the RNA chains in a nonselective manner (Figure 8) $[56,127,128]$. 


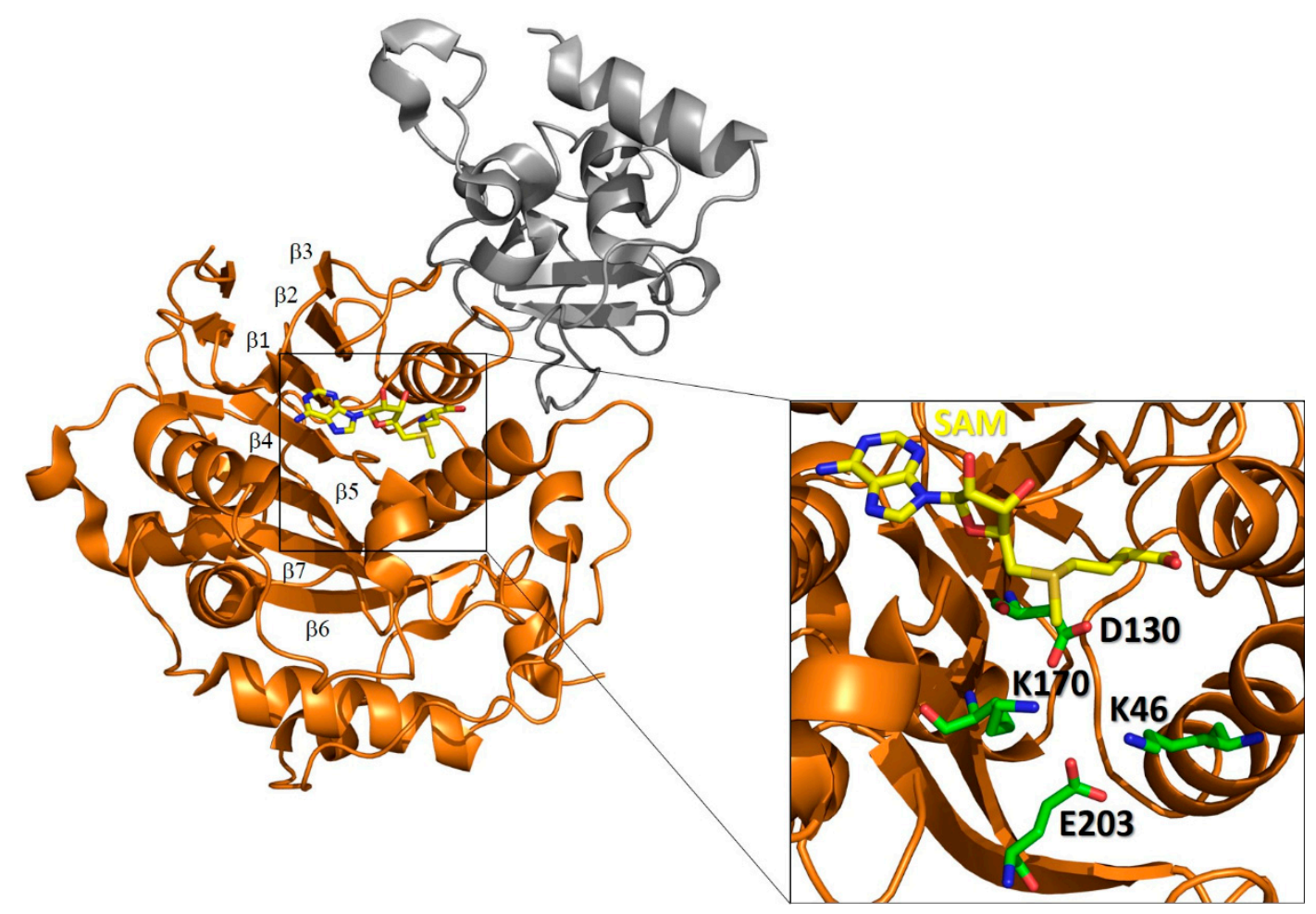

Figure 8. Structure of the SARS-CoV-2 Nsp10-Nsp16 complex. Cartoon representation of the crystal structure complex (PDB code 6W4H) of Nsp16 (orange) in complex with Nsp10 (grey). The inset shows the catalytic site of Nsp16. Catalytic residues (green) and the SAM ligand (yellow) are shown in stick form.

Mutagenesis studies confirmed the central role played by the K-D-K-E tetrad of Nsp16 for the 2 O-MTase activity [52]. Infection of small animal models with viruses expressing Nsp16 mutants showed a decrease in viral titers. These findings suggest that the inhibition of the viral 2 O-MTase activity, and the consequent production of an incompletely capped RNA, might stimulate the detection of viral RNA by pathogen-associated molecular patterns (PAMPs) and induce a host antiviral response. Indeed, it was shown that the incompletely capped RNA can be detected by the cytosolic RIG-I-like receptors (RLRs) RIG-I or Mda5 [125,129-131], which stimulate the production of type I interferon (IFN). The resulting IFN secretion induces the host antiviral response mediated by IFN-induced protein with tetratricopeptide repeats (IFIT) proteins [132,133].

As shown in the case of SARS-CoV, Nsp16 needs to interact with Nsp10 to become active [53]. Indeed, SARS CoV Nsp16 alone has low affinity for both m7GpppA-RNA and m7GpppA cap analogue, and the interaction between the two proteins increases RNA-binding affinity [53]. Similar results were observed for MERS CoV Nsp16/Nsp10 complex [125].

As previously discussed, the cofactor Nsp10 plays a similar activating role for Nsp14, as demonstrated for SARS-CoV [98]. Therefore, we explored the possibility of the formation of a ternary complex Nsp10/Nsp14/Nsp16 by verifying the compatibility of binding of Nsp14 and Nsp16 to Nsp10 (see caption for Figure 9 for details). As shown in Figure 9, interacting regions on Nsp10 with Nsp14 and Nsp16 are perfectly complementary, thus allowing for a simultaneous interaction of Nsp10 with both Nsp14 and Nsp16. This finding suggests it is likely that Nsp10 works not only as an allosteric activator of the two enzymes but also as a molecular connector, joining three catalytic sites together in space (Figure 9). As shown in Figure 9, a ternary complex Nsp10-Nsp14-Nsp16 would keep the proofreading site of Nsp14 close in space to the two catalytic sites responsible for capping on Nsp14 and on Nsp16. This ternary complex is likely only a part of a large RNA polymerase complex, which is further hold together by the known interactions between the ExoN domain of Nsp14 and Nsp12 [29] 
and between Nsp13 and Nsp12 [59], although fine details of these interactions are still unknown (Figure 9). In the case of a nucleotide mismatch, the nascent RNA strand can be efficiently moved from Nsp12 to the ExoN site of the RNA polymerase complex for excision (Figure 9). Final capping is then provided by the sequential activities of close-in-space enzymes. Namely, the Nsp13 helicase, the GTase and then the N7-MTase activity of Nsp14 and the 2'-OMTase activity of Nsp16 (Figure 9), thus completing the nascent RNA strand with the cap1 structure at its $5^{\prime}$ end.

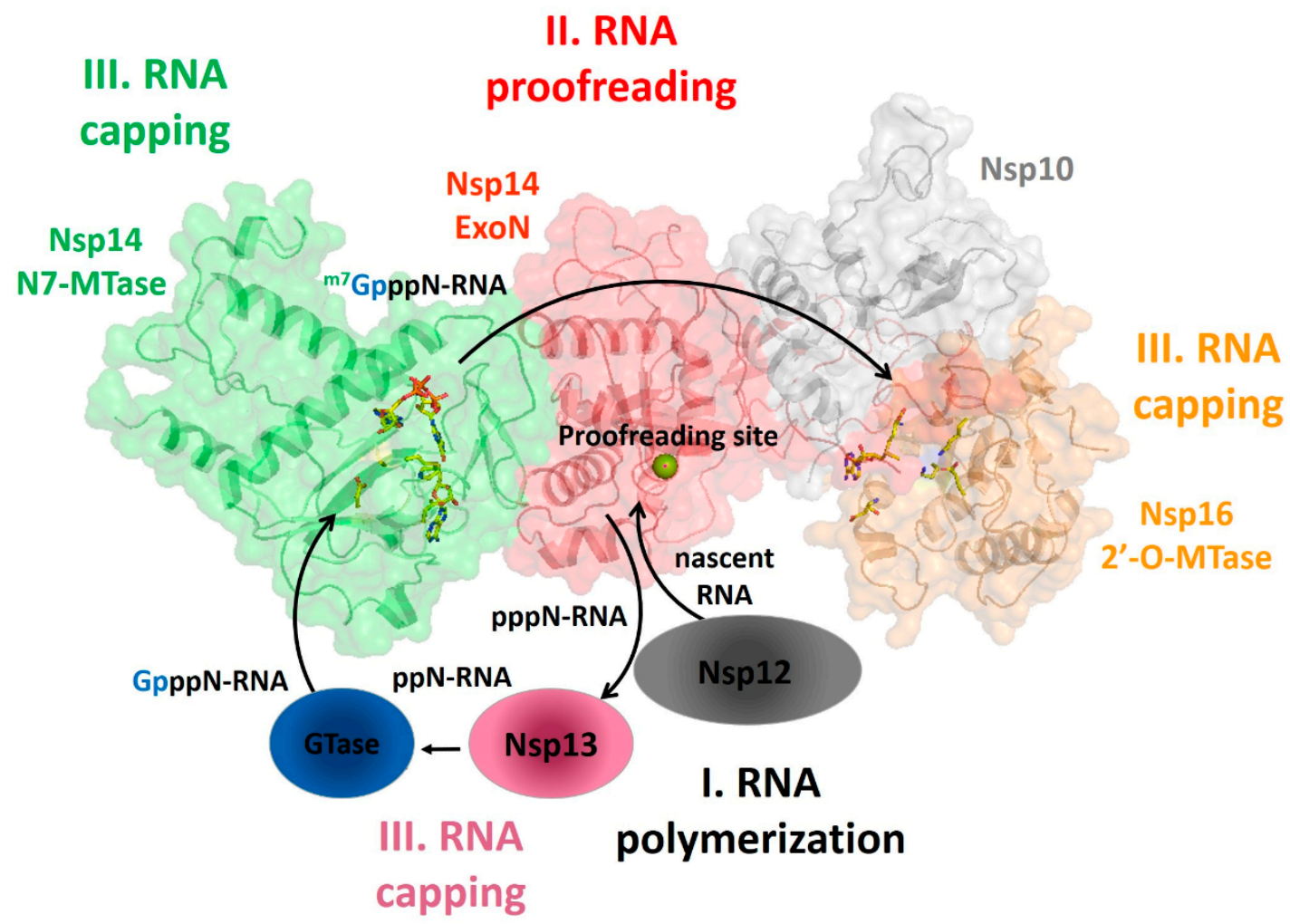

Figure 9. Nsp10 as a molecular connector between proofreading and capping activities. Cartoon and surface representation of the macromolecular complex generated upon superposition of Nsp10 in the two complexes Nsp14-Nsp10 and Nsp16-Nsp10. This model was obtained upon superposition of Nsp10 cofactors of the Nsp10/Nsp14 and Nsp10/Nsp16 complexes, using CCP4. A nascent RNA strand polymerized by Nsp12 (grey oval) is proofread by Nsp14, dephosphorylated by Nsp13 and then capped by GTase, Nsp14 and finally Nsp16.

\section{Concluding Remarks}

Over the past ten years, we have observed the emergence of many different coronaviruses, that have caused serious diseases like SARS in 2002, MERS in 2012 and currently, COVID19. It is more than likely that coronaviruses will emerge again in the near future due to their ability to mutate, recombine and infect different hosts, as we have just observed for SARS-CoV-2, which has evolved from a bat disease to a human disease outbreak. A possible strategy is to identify those processes that are more preserved in all coronaviruses and deeply understand their mechanisms. By inhibiting these processes there is a great chance of developing a pancoronaviral therapeutic strategy. As discussed in this review, molecular actors responsible for RNA replication are among the most conserved coronaviral proteins and therefore deserve deep understanding of their structural properties. The composition and structural organization of the replicase complex of SARS-CoV-2 has not been thoroughly studied, although research in the field is progressing fast. However, there are many lessons to be learnt from studies of the RNA replication of similar viruses, as reported in this review. These studies, both structural and functional, have identified and described enzymes responsible for RNA polymerization, proofreading and final capping mechanisms to produce stable RNA. However, an important role is 
also played by cofactors, which mediate protein-protein interactions and thus conduct the orchestra of RNA processing enzymes to improve their efficiencies. Gaining a complete picture of the intricate process of RNA replication of SARS-CoV-2 significantly improves our ability to design therapeutic tools to reduce disease burden.

Supplementary Materials: The following are available online at http://www.mdpi.com/2073-4409/9/5/1267/s1, Figure S1: Model of SARS-CoV-2 elongation complex, Table S1: Sequence identities of SARS-CoV2 Nsps with homologous proteins.

Author Contributions: Conceptualization, R.B. and A.R.; methodology and software, R.B., M.R. and A.R.; formal analysis, M.R., F.S. and A.R.; data curation, M.R. and R.B.; writing original draft preparation, R.B.; writing review and editing, R.B. and G.M.; supervision, R.B.; funding acquisition, R.B. All authors have read and agreed to the published version of the manuscript.

Funding: This research was supported by the project RECOVER-COVID19, funded by Regione Campania, Italy.

Acknowledgments: We would like to acknowledge the help of our technical staff, including Maurizio Amendola and Luca De Luca.

Conflicts of Interest: The authors declare no conflict of interest. The funders had no role in the design of the study; in the collection, analyses, or interpretation of data; in the writing of the manuscript, or in the decision to publish the results.

\section{Abbreviations}

$\begin{array}{ll}\text { WHO } & \text { World Health Organization } \\ \text { DMV } & \text { Double-membrane vesicles } \\ \text { PDB } & \text { Protein Data Bank } \\ \text { SARS } & \text { Severe acute respiratory syndrome } \\ \text { MERS } & \text { Middle East respiratory syndrome } \\ \text { EBOV } & \text { Ebola virus } \\ \text { NIV } & \text { Nipah virus } \\ \text { RSV } & \text { Respiratory syncytial virus } \\ \text { EAV } & \text { Equine arteritis virus } \\ \text { RNP } & \text { Ribonucleocapsid } \\ \text { Nsp } & \text { Non-structural protein } \\ \text { RdRP } & \text { RNA dependent RNA polymerase } \\ \text { NiRAN } & \text { Nidovirus RdRp-associated nucleotidyltransferase } \\ \text { NTP } & \text { Nucleoside triphosphate } \\ \text { PAMP } & \text { Pathogen-associated molecular pattern }\end{array}$

\section{References}

1. Zhou, P.; Yang, X.L.; Wang, X.G.; Hu, B.; Zhang, L.; Zhang, W.; Si, H.R.; Zhu, Y.; Li, B.; Huang, C.L.; et al. A pneumonia outbreak associated with a new coronavirus of probable bat origin. Nature 2020, 579, 270-273. [CrossRef]

2. Wu, J.T.; Leung, K.; Leung, G.M. Nowcasting and forecasting the potential domestic and international spread of the 2019-nCoV outbreak originating in Wuhan, China: A modelling study. Lancet 2020, 395, 689-697. [CrossRef]

3. Lu, R.; Zhao, X.; Li, J.; Niu, P.; Yang, B.; Wu, H.; Wang, W.; Song, H.; Huang, B.; Zhu, N.; et al. Genomic characterisation and epidemiology of 2019 novel coronavirus: Implications for virus origins and receptor binding. Lancet 2020, 395, 565-574. [CrossRef]

4. Luan, J.; Lu, Y.; Jin, X.; Zhang, L. Spike protein recognition of mammalian ACE2 predicts the host range and an optimized ACE2 for SARS-CoV-2 infection. Biochem. Biophys. Res. Commun. 2020. [CrossRef] [PubMed]

5. Wrapp, D.; Wang, N.; Corbett, K.S.; Goldsmith, J.A.; Hsieh, C.L.; Abiona, O.; Graham, B.S.; McLellan, J.S. Cryo-EM structure of the 2019-nCoV spike in the prefusion conformation. Science 2020, 367, 1260-1263. [CrossRef]

6. Wang, K.; Chen, W.; Zhou, Y.-S.; Lian, J.-Q.; Zhang, Z.; Du, P.; Gong, L.; Zhang, Y.; Cui, H.-Y.; Geng, J.-J.; et al. SARS-CoV-2 invades host cells via a novel route: CD147-spike protein. BioRxiv 2020. [CrossRef] 
7. Hoffmann, M.; Kleine-Weber, H.; Schroeder, S.; Krüger, N.; Herrler, T.; Erichsen, S.; Schiergens, T.S.; Herrler, G.; Wu, N.H.; Nitsche, A.; et al. SARS-CoV-2 Cell Entry Depends on ACE2 and TMPRSS2 and Is Blocked by a Clinically Proven Protease Inhibitor. Cell 2020. [CrossRef]

8. Yang, N.; Shen, H.M. Targeting the Endocytic Pathway and Autophagy Process as a Novel Therapeutic Strategy in COVID-19. Int. J. Biol. Sci. 2020, 16, 1724-1731. [CrossRef]

9. Xia, S.; Zhu, Y.; Liu, M.; Lan, Q.; Xu, W.; Wu, Y.; Ying, T.; Liu, S.; Shi, Z.; Jiang, S.; et al. Fusion mechanism of 2019-nCoV and fusion inhibitors targeting HR1 domain in spike protein. Cell. Mol. Immunol. 2020. [CrossRef]

10. Gordon, D.E.; Jang, G.M.; Bouhaddou, M.; Krogan, N.J. A SARS-CoV-2-Human Protein-Protein Interaction Map Reveals Drug Targets and Potential Drug-Repurposing. BioXriv 2020. [CrossRef]

11. Brai, A.; Martelli, F.; Riva, V.; Garbelli, A.; Fazi, R.; Zamperini, C.; Pollutri, A.; Falsitta, L.; Ronzini, S.; Maccari, L.; et al. DDX3X Helicase Inhibitors as a New Strategy To Fight the West Nile Virus Infection. J Med. Chem. 2019, 62, 2333-2347. [CrossRef] [PubMed]

12. Brai, A.; Fazi, R.; Tintori, C.; Zamperini, C.; Bugli, F.; Sanguinetti, M.; Stigliano, E.; Este, J.; Badia, R.; Franco, S.; et al. Human DDX3 protein is a valuable target to develop broad spectrum antiviral agents. Proc. Natl. Acad. Sci. USA 2016, 113, 5388-5393. [CrossRef] [PubMed]

13. Wu, A.; Peng, Y.; Huang, B.; Ding, X.; Wang, X.; Niu, P.; Meng, J.; Zhu, Z.; Zhang, Z.; Wang, J.; et al. Genome Composition and Divergence of the Novel Coronavirus (2019-nCoV) Originating in China. Cell Host Microbe 2020, 27, 325-328. [CrossRef]

14. Sola, I.; Almazan, F.; Zuniga, S.; Enjuanes, L. Continuous and Discontinuous RNA Synthesis in Coronaviruses. Annu. Rev. Virol. 2015, 2, 265-288. [CrossRef] [PubMed]

15. Gorbalenya, A.E.; Enjuanes, L.; Ziebuhr, J.; Snijder, E.J. Nidovirales: Evolving the largest RNA virus genome. Virus Res. 2006, 117, 17-37. [CrossRef] [PubMed]

16. Wu, F.; Zhao, S.; Yu, B.; Chen, Y.M.; Wang, W.; Song, Z.G.; Hu, Y.; Tao, Z.W.; Tian, J.H.; Pei, Y.Y.; et al. A new coronavirus associated with human respiratory disease in China. Nature 2020, 579, 265-269. [CrossRef] [PubMed]

17. Dufour, D.; Mateos-Gomez, P.A.; Enjuanes, L.; Gallego, J.; Sola, I. Structure and functional relevance of a transcription-regulating sequence involved in coronavirus discontinuous RNA synthesis. J. Virol. 2011, 85, 4963-4973. [CrossRef]

18. Mateos-Gomez, P.A.; Morales, L.; Zuniga, S.; Enjuanes, L.; Sola, I. Long-distance RNA-RNA interactions in the coronavirus genome form high-order structures promoting discontinuous RNA synthesis during transcription. J. Virol. 2013, 87, 177-186. [CrossRef]

19. Knoops, K.; Kikkert, M.; Worm, S.H.; Zevenhoven-Dobbe, J.C.; van der Meer, Y.; Koster, A.J.; Mommaas, A.M.; Snijder, E.J. SARS-coronavirus replication is supported by a reticulovesicular network of modified endoplasmic reticulum. PLoS Biol. 2008, 6, e226. [CrossRef]

20. Cheng, A.; Zhang, W.; Xie, Y.; Jiang, W.; Arnold, E.; Sarafianos, S.G.; Ding, J. Expression, purification, and characterization of SARS coronavirus RNA polymerase. Virology 2005, 335, 165-176. [CrossRef]

21. Ivanov, K.A.; Thiel, V.; Dobbe, J.C.; van der Meer, Y.; Snijder, E.J.; Ziebuhr, J. Multiple enzymatic activities associated with severe acute respiratory syndrome coronavirus helicase. J. Virol. 2004, 78, 5619-5632. [CrossRef]

22. Feder, M.; Pas, J.; Wyrwicz, L.S.; Bujnicki, J.M. Molecular phylogenetics of the RrmJ/fibrillarin superfamily of ribose 2'-O-methyltransferases. Gene 2003, 302, 129-138. [CrossRef]

23. Snijder, E.J.; Bredenbeek, P.J.; Dobbe, J.C.; Thiel, V.; Ziebuhr, J.; Poon, L.L.; Guan, Y.; Rozanov, M.; Spaan, W.J.; Gorbalenya, A.E. Unique and conserved features of genome and proteome of SARS-coronavirus, an early split-off from the coronavirus group 2 lineage. J. Mol. Biol. 2003, 331, 991-1004. [CrossRef]

24. Sevajol, M.; Subissi, L.; Decroly, E.; Canard, B.; Imbert, I. Insights into RNA synthesis, capping, and proofreading mechanisms of SARS-coronavirus. Virus Res. 2014, 194, 90-99. [CrossRef] [PubMed]

25. Bhardwaj, K.; Guarino, L.; Kao, C.C. The severe acute respiratory syndrome coronavirus Nsp15 protein is an endoribonuclease that prefers manganese as a cofactor. J. Virol. 2004, 78, 12218-12224. [CrossRef]

26. Ivanov, K.A.; Hertzig, T.; Rozanov, M.; Bayer, S.; Thiel, V.; Gorbalenya, A.E.; Ziebuhr, J. Major genetic marker of nidoviruses encodes a replicative endoribonuclease. Proc. Natl. Acad. Sci. USA 2004, 101, 12694-12699. [CrossRef] 
27. Deng, X.; Hackbart, M.; Mettelman, R.C.; O’Brien, A.; Mielech, A.M.; Yi, G.; Kao, C.C.; Baker, S.C. Coronavirus nonstructural protein 15 mediates evasion of dsRNA sensors and limits apoptosis in macrophages. Proc. Natl. Acad. Sci. USA 2017, 114, E4251-E4260. [CrossRef]

28. Imbert, I.; Guillemot, J.C.; Bourhis, J.M.; Bussetta, C.; Coutard, B.; Egloff, M.P.; Ferron, F.; Gorbalenya, A.E.; Canard, B. A second, non-canonical RNA-dependent RNA polymerase in SARS coronavirus. EMBO J. 2006, 25, 4933-4942. [CrossRef]

29. Subissi, L.; Posthuma, C.C.; Collet, A.; Zevenhoven-Dobbe, J.C.; Gorbalenya, A.E.; Decroly, E.; Snijder, E.J.; Canard, B.; Imbert, I. One severe acute respiratory syndrome coronavirus protein complex integrates processive RNA polymerase and exonuclease activities. Proc. Natl. Acad. Sci. USA 2014, 111, E3900-E3909. [CrossRef]

30. Bouvet, M.; Lugari, A.; Posthuma, C.C.; Zevenhoven, J.C.; Bernard, S.; Betzi, S.; Imbert, I.; Canard, B.; Guillemot, J.C.; Lécine, P.; et al. Coronavirus Nsp10, a critical co-factor for activation of multiple replicative enzymes. J. Biol. Chem. 2014, 289, 25783-25796. [CrossRef]

31. Angelini, M.M.; Akhlaghpour, M.; Neuman, B.W.; Buchmeier, M.J. Severe acute respiratory syndrome coronavirus nonstructural proteins 3, 4, and 6 induce double-membrane vesicles. mBio 2013, 4. [CrossRef] [PubMed]

32. Sawicki, S.G.; Sawicki, D.L.; Siddell, S.G. A contemporary view of coronavirus transcription. J. Virol. 2007, 81, 20-29. [CrossRef] [PubMed]

33. Kamitani, W.; Huang, C.; Narayanan, K.; Lokugamage, K.G.; Makino, S. A two-pronged strategy to suppress host protein synthesis by SARS coronavirus Nsp1 protein. Nat. Struct. Mol. Biol. 2009, 16, 1134-1140. [CrossRef] [PubMed]

34. Narayanan, K.; Huang, C.; Lokugamage, K.; Kamitani, W.; Ikegami, T.; Tseng, C.T.; Makino, S. Severe acute respiratory syndrome coronavirus nsp1 suppresses host gene expression, including that of type I interferon, in infected cells. J. Virol. 2008, 82, 4471-4479. [CrossRef]

35. McBride, R.; van Zyl, M.; Fielding, B.C. The coronavirus nucleocapsid is a multifunctional protein. Viruses 2014, 6, 2991-3018. [CrossRef]

36. De Haan, C.A.; Rottier, P.J. Molecular interactions in the assembly of coronaviruses. Adv. Virus Res. 2005, 64, 165-230. [CrossRef]

37. Lai, M.M.; Cavanagh, D. The molecular biology of coronaviruses. Adv. Virus Res. 1997, 48, 1-100.

38. Tahara, S.M.; Dietlin, T.A.; Bergmann, C.C.; Nelson, G.W.; Kyuwa, S.; Anthony, R.P.; Stohlman, S.A. Coronavirus translational regulation: Leader affects mRNA efficiency. Virology 1994, 202, 621-630. [CrossRef]

39. Tahara, S.M.; Dietlin, T.A.; Nelson, G.W.; Stohlman, S.A.; Manno, D.J. Mouse hepatitis virus nucleocapsid protein as a translational effector of viral mRNAs. Adv. Exp. Med. Biol. 1998, 440, 313-318. [CrossRef]

40. Chang, C.K.; Hou, M.H.; Chang, C.F.; Hsiao, C.D.; Huang, T.H. The SARS coronavirus nucleocapsid protein-forms and functions. Antivir. Res. 2014, 103, 39-50. [CrossRef]

41. Sturman, L.S.; Holmes, K.V.; Behnke, J. Isolation of coronavirus envelope glycoproteins and interaction with the viral nucleocapsid. J. Virol. 1980, 33, 449-462. [CrossRef] [PubMed]

42. Kuo, L.; Masters, P.S. Genetic evidence for a structural interaction between the carboxy termini of the membrane and nucleocapsid proteins of mouse hepatitis virus. J. Virol. 2002, 76, 4987-4999. [CrossRef] [PubMed]

43. De Haan, C.A.; Kuo, L.; Masters, P.S.; Vennema, H.; Rottier, P.J. Coronavirus particle assembly: Primary structure requirements of the membrane protein. J. Virol. 1998, 72, 6838-6850. [CrossRef] [PubMed]

44. De Haan, C.A.; Smeets, M.; Vernooij, F.; Vennema, H.; Rottier, P.J. Mapping of the coronavirus membrane protein domains involved in interaction with the spike protein. J. Virol. 1999, 73, 7441-7452. [CrossRef] [PubMed]

45. Peti, W.; Johnson, M.A.; Herrmann, T.; Neuman, B.W.; Buchmeier, M.J.; Nelson, M.; Joseph, J.; Page, R.; Stevens, R.C.; Kuhn, P.; et al. Structural genomics of the severe acute respiratory syndrome coronavirus: Nuclear magnetic resonance structure of the protein nsP7. J. Virol. 2005, 79, 12905-12913. [CrossRef]

46. Johnson, M.A.; Jaudzems, K.; Wüthrich, K. NMR Structure of the SARS-CoV Nonstructural Protein 7 in Solution at pH 6.5. J. Mol. Biol. 2010, 402, 619-628. [CrossRef]

47. Zhai, Y.; Sun, F.; Li, X.; Pang, H.; Xu, X.; Bartlam, M.; Rao, Z. Insights into SARS-CoV transcription and replication from the structure of the nsp7-nsp8 hexadecamer. Nat. Struct. Mol. Biol. 2005, 12, 980-986. [CrossRef] 
48. Kirchdoerfer, R.N.; Ward, A.B. Structure of the SARS-CoV nsp12 polymerase bound to nsp7 and nsp8 co-factors. Nat. Commun. 2019, 10, 2342. [CrossRef]

49. Littler, D.R.; Gully, B.S.; Colson, R.N.; Rossjohn, J. Crystal structure of the SARS-CoV-2 non-structural protein 9, Nsp9. BioXriv 2020. [CrossRef]

50. Egloff, M.P.; Ferron, F.; Campanacci, V.; Longhi, S.; Rancurel, C.; Dutartre, H.; Snijder, E.J.; Gorbalenya, A.E.; Cambillau, C.; Canard, B. The severe acute respiratory syndrome-coronavirus replicative protein nsp9 is a single-stranded RNA-binding subunit unique in the RNA virus world. Proc. Natl. Acad. Sci. USA 2004, 101, 3792-3796. [CrossRef]

51. Sutton, G.; Fry, E.; Carter, L.; Sainsbury, S.; Walter, T.; Nettleship, J.; Berrow, N.; Owens, R.; Gilbert, R.; Davidson, A.; et al. The nsp9 replicase protein of SARS-coronavirus, structure and functional insights. Structure 2004, 12, 341-353. [CrossRef] [PubMed]

52. Decroly, E.; Debarnot, C.; Ferron, F.; Bouvet, M.; Coutard, B.; Imbert, I.; Gluais, L.; Papageorgiou, N.; Sharff, A.; Bricogne, G.; et al. Crystal Structure and Functional Analysis of the SARS-Coronavirus RNA Cap 2 '-O-Methyltransferase nsp10/nsp16 Complex. PLoS Pathog. 2011, 7, e1002059. [CrossRef] [PubMed]

53. Chen, Y.; Su, C.Y.; Ke, M.; Jin, X.; Xu, L.R.; Zhang, Z.; Wu, A.D.; Sun, Y.; Yang, Z.N.; Tien, P.; et al. Biochemical and Structural Insights into the Mechanisms of SARS Coronavirus RNA Ribose 2 '-O-Methylation by nsp16/nsp10 Protein Complex. PLoS Pathog. 2011, 7, e1002294. [CrossRef] [PubMed]

54. Ferron, F.; Subissi, L.; De Morais, A.T.S.; Le, N.T.T.; Sevajol, M.; Gluais, L.; Decroly, E.; Vonrhein, C.; Bricogne, G.; Canard, B.; et al. Structural and molecular basis of mismatch correction and ribavirin excision from coronavirus RNA. Proc. Natl. Acad. Sci. USA 2018, 115, E162-E171. [CrossRef]

55. Ma, Y.; Wu, L.; Shaw, N.; Gao, Y.; Wang, J.; Sun, Y.; Lou, Z.; Yan, L.; Zhang, R.; Rao, Z. Structural basis and functional analysis of the SARS coronavirus nsp14-nsp10 complex. Proc. Natl. Acad. Sci. USA 2015, 112, 9436-9441. [CrossRef]

56. Su, D.; Lou, Z.Y.; Sun, F.; Zhai, Y.J.; Yang, H.T.; Zhang, R.G.; Joachimiak, A.; Zhang, X.J.C.; Bartlam, M.; Rao, Z.H. Dodecamer structure of severe acute respiratory syndrome coronavirus nonstructural protein nsp10. J. Virol. 2006, 80, 7902-7908. [CrossRef]

57. Gao, Y.; Yan, L.; Huang, Y.; Liu, F.; Zhao, Y.; Cao, L.; Wang, T.; Sun, Q.; Ming, Z.; Zhang, L.; et al. Structure of the RNA-dependent RNA polymerase from COVID-19 virus. Science 2020. [CrossRef]

58. Yin, W.; Mao, C.; Luan, X.; Shen, D.-D.; Shen, Q.; Su, H.; Wang, X.; Zhou, F.; Zhao, W.; Gao, M.; et al. Structural Basis for the Inhibition of the RNA-Dependent RNA Polymerase from SARS-CoV-2 by Remdesivir. BioXriv 2020. [CrossRef]

59. Jia, Z.; Yan, L.; Ren, Z.; Wu, L.; Wang, J.; Guo, J.; Zheng, L.; Ming, Z.; Zhang, L.; Lou, Z.; et al. Delicate structural coordination of the Severe Acute Respiratory Syndrome coronavirus Nsp13 upon ATP hydrolysis. Nucleic Acids Res. 2019, 47, 6538-6550. [CrossRef]

60. Hao, W.; Wojdyla, J.A.; Zhao, R.; Han, R.; Das, R.; Zlatev, I.; Manoharan, M.; Wang, M.; Cui, S. Crystal structure of Middle East respiratory syndrome coronavirus helicase. PLoS Pathog. 2017, 13, e1006474. [CrossRef]

61. Kim, Y.; Jedrzejczak, R.; Maltseva, N.I.; Wilamowski, M.; Endres, M.; Godzik, A.; Michalska, K.; Joachimiak, A. Crystal structure of Nsp15 endoribonuclease NendoU from SARS-CoV-2. BioXriv 2020. [CrossRef] [PubMed]

62. Ricagno, S.; Egloff, M.P.; Ulferts, R.; Coutard, B.; Nurizzo, D.; Campanacci, V.; Cambillau, C.; Ziebuhr, J.; Canard, B. Crystal structure and mechanistic determinants of SARS coronavirus nonstructural protein 15 define an endoribonuclease family. Proc. Natl. Acad. Sci. USA 2006, 103, 11892-11897. [CrossRef]

63. Bhardwaj, K.; Palaninathan, S.; Alcantara, J.M.; Yi, L.L.; Guarino, L.; Sacchettini, J.C.; Kao, C.C. Structural and functional analyses of the severe acute respiratory syndrome coronavirus endoribonuclease Nsp15. J. Biol. Chem. 2008, 283, 3655-3664. [CrossRef]

64. Cameron, C.E.; Götte, M.; Raney, K.D. Viral Genome Replication; Springer: Boston, MA, USA, 2009.

65. Von Brunn, A.; Teepe, C.; Simpson, J.C.; Pepperkok, R.; Friedel, C.C.; Zimmer, R.; Roberts, R.; Baric, R.; Haas, J. Analysis of intraviral protein-protein interactions of the SARS coronavirus ORFeome. PLoS ONE 2007, 2, e459. [CrossRef]

66. Tan, Y.W.; Fung, T.S.; Shen, H.; Huang, M.; Liu, D.X. Coronavirus infectious bronchitis virus non-structural proteins 8 and 12 form stable complex independent of the non-translated regions of viral RNA and other viral proteins. Virology 2018, 513, 75-84. [CrossRef] [PubMed] 
67. Seybert, A.; Posthuma, C.C.; van Dinten, L.C.; Snijder, E.J.; Gorbalenya, A.E.; Ziebuhr, J. A complex zinc finger controls the enzymatic activities of nidovirus helicases. J. Virol. 2005, 79, 696-704. [CrossRef] [PubMed]

68. Lehmann, K.C.; Snijder, E.J.; Posthuma, C.C.; Gorbalenya, A.E. What we know but do not understand about nidovirus helicases. Virus Res. 2015, 202, 12-32. [CrossRef] [PubMed]

69. Brockway, S.M.; Clay, C.T.; Lu, X.T.; Denison, M.R. Characterization of the expression, intracellular localization, and replication complex association of the putative mouse hepatitis virus RNA-dependent RNA polymerase. J. Virol. 2003, 77, 10515-10527. [CrossRef]

70. Zhang, L.; Li, L.; Yan, L.; Ming, Z.; Jia, Z.; Lou, Z.; Rao, Z. Structural and Biochemical Characterization of Endoribonuclease Nsp15 Encoded by Middle East Respiratory Syndrome Coronavirus. J. Virol. 2018, 92, e00893-18. [CrossRef]

71. Athmer, J.; Fehr, A.R.; Grunewald, M.; Smith, E.C.; Denison, M.R.; Perlman, S. In Situ Tagged nsp15 Reveals Interactions with Coronavirus Replication/Transcription Complex-Associated Proteins. mBio 2017, 8, e02320-16. [CrossRef]

72. Deming, D.J.; Graham, R.L.; Denison, M.R.; Baric, R.S. Processing of open reading frame 1a replicase proteins nsp7 to nsp10 in murine hepatitis virus strain A59 replication. J. Virol. 2007, 81, 10280-10291. [CrossRef] [PubMed]

73. Lehmann, K.C.; Gulyaeva, A.; Zevenhoven-Dobbe, J.C.; Janssen, G.M.; Ruben, M.; Overkleeft, H.S.; van Veelen, P.A.; Samborskiy, D.V.; Kravchenko, A.A.; Leontovich, A.M.; et al. Discovery of an essential nucleotidylating activity associated with a newly delineated conserved domain in the RNA polymerase-containing protein of all nidoviruses. Nucleic Acids Res. 2015, 43, 8416-8434. [CrossRef] [PubMed]

74. Liau, N.P.D.; Laktyushin, A.; Lucet, I.S.; Murphy, J.M.; Yao, S.; Whitlock, E.; Callaghan, K.; Nicola, N.A.; Kershaw, N.J.; Babon, J.J. The molecular basis of JAK/STAT inhibition by SOCS1. Nat. Commun. 2018, 9, 1558. [CrossRef]

75. Arnold, J.J.; Cameron, C.E. Poliovirus RNA-dependent RNA polymerase (3D(pol)). Assembly of stable, elongation-competent complexes by using a symmetrical primer-template substrate (sym/sub). J. Biol. Chem. 2000, 275, 5329-5336. [CrossRef]

76. Arias, A.; Arnold, J.J.; Sierra, M.; Smidansky, E.D.; Domingo, E.; Cameron, C.E. Determinants of RNA-dependent RNA polymerase (in)fidelity revealed by kinetic analysis of the polymerase encoded by a foot-and-mouth disease virus mutant with reduced sensitivity to ribavirin. J. Virol. 2008, 82, 12346-12355. [CrossRef]

77. Gong, P.; Peersen, O.B. Structural basis for active site closure by the poliovirus RNA-dependent RNA polymerase. Proc. Natl. Acad. Sci. USA 2010, 107, 22505-22510. [CrossRef]

78. Warren, T.K.; Jordan, R.; Lo, M.K.; Ray, A.S.; Mackman, R.L.; Soloveva, V.; Siegel, D.; Perron, M.; Bannister, R.; Hui, H.C.; et al. Therapeutic efficacy of the small molecule GS-5734 against Ebola virus in rhesus monkeys. Nature 2016, 531, 381-385. [CrossRef]

79. Agostini, M.L.; Andres, E.L.; Sims, A.C.; Graham, R.L.; Sheahan, T.P.; Lu, X.; Smith, E.C.; Case, J.B.; Feng, J.Y.; Jordan, R.; et al. Coronavirus Susceptibility to the Antiviral Remdesivir (GS-5734) Is Mediated by the Viral Polymerase and the Proofreading Exoribonuclease. mBio 2018, 9, e00221-18. [CrossRef]

80. Brown, A.J.; Won, J.J.; Graham, R.L.; Dinnon, K.H., 3rd; Sims, A.C.; Feng, J.Y.; Cihlar, T.; Denison, M.R.; Baric, R.S.; Sheahan, T.P. Broad spectrum antiviral remdesivir inhibits human endemic and zoonotic deltacoronaviruses with a highly divergent RNA dependent RNA polymerase. Antivir. Res. 2019, 169, 104541. [CrossRef]

81. Wang, M.; Cao, R.; Zhang, L.; Yang, X.; Liu, J.; Xu, M.; Shi, Z.; Hu, Z.; Zhong, W.; Xiao, G. Remdesivir and chloroquine effectively inhibit the recently emerged novel coronavirus (2019-nCoV) in vitro. Cell Res. 2020, 30, 269-271. [CrossRef]

82. De Wit, E.; Feldmann, F.; Cronin, J.; Jordan, R.; Okumura, A.; Thomas, T.; Scott, D.; Cihlar, T.; Feldmann, H. Prophylactic and therapeutic remdesivir (GS-5734) treatment in the rhesus macaque model of MERS-CoV infection. Proc. Natl. Acad. Sci. USA 2020, 117, 6771-6776. [CrossRef] [PubMed]

83. Lo, M.K.; Jordan, R.; Arvey, A.; Sudhamsu, J.; Shrivastava-Ranjan, P.; Hotard, A.L.; Flint, M.; McMullan, L.K.; Siegel, D.; Clarke, M.O.; et al. GS-5734 and its parent nucleoside analog inhibit Filo-, Pneumo-, and Paramyxoviruses. Sci Rep 2017, 7, 43395. [CrossRef] [PubMed] 
84. Sheahan, T.P.; Sims, A.C.; Graham, R.L.; Menachery, V.D.; Gralinski, L.E.; Case, J.B.; Leist, S.R.; Pyrc, K.; Feng, J.Y.; Trantcheva, I.; et al. Broad-spectrum antiviral GS-5734 inhibits both epidemic and zoonotic coronaviruses. Sci. Transl. Med. 2017, 9. [CrossRef] [PubMed]

85. Sheahan, T.P.; Sims, A.C.; Leist, S.R.; Schafer, A.; Won, J.; Brown, A.J.; Montgomery, S.A.; Hogg, A.; Babusis, D.; Clarke, M.O.; et al. Comparative therapeutic efficacy of remdesivir and combination lopinavir, ritonavir, and interferon beta against MERS-CoV. Nat. Commun. 2020, 11, 222. [CrossRef]

86. Cardile, A.P.; Warren, T.K.; Martins, K.A.; Reisler, R.B.; Bavari, S. Will There Be a Cure for Ebola? Annu. Rev. Pharmacol. Toxicol. 2017, 57, 329-348. [CrossRef]

87. Jordan, P.C.; Liu, C.; Raynaud, P.; Lo, M.K.; Spiropoulou, C.F.; Symons, J.A.; Beigelman, L.; Deval, J. Initiation, extension, and termination of RNA synthesis by a paramyxovirus polymerase. PLoS Pathog. 2018, 14, e1006889. [CrossRef]

88. Tchesnokov, E.P.; Feng, J.Y.; Porter, D.P.; Gotte, M. Mechanism of Inhibition of Ebola Virus RNA-Dependent RNA Polymerase by Remdesivir. Viruses 2019, 11, 326. [CrossRef]

89. Gordon, C.J.; Tchesnokov, E.P.; Feng, J.Y.; Porter, D.P.; Gotte, M. The antiviral compound remdesivir potently inhibits RNA-dependent RNA polymerase from Middle East respiratory syndrome coronavirus. J. Biol. Chem. 2020, 295, 4773-4779. [CrossRef]

90. Holshue, M.L.; DeBolt, C.; Lindquist, S.; Lofy, K.H.; Wiesman, J.; Bruce, H.; Spitters, C.; Ericson, K.; Wilkerson, S.; Tural, A.; et al. First Case of 2019 Novel Coronavirus in the United States. N. Engl. J. Med. 2020, 382, 929-936. [CrossRef]

91. Lai, C.C.; Shih, T.P.; Ko, W.C.; Tang, H.J.; Hsueh, P.R. Severe acute respiratory syndrome coronavirus 2 (SARS-CoV-2) and coronavirus disease-2019 (COVID-19): The epidemic and the challenges. Int. J. Antimicrob. Agents 2020, 55, 105924. [CrossRef]

92. Ogando, N.S.; Ferron, F.; Decroly, E.; Canard, B.; Posthuma, C.C.; Snijder, E.J. The Curious Case of the Nidovirus Exoribonuclease: Its Role in RNA Synthesis and Replication Fidelity. Front. Microbiol. 2019, 10, 1813. [CrossRef]

93. Becares, M.; Pascual-Iglesias, A.; Nogales, A.; Sola, I.; Enjuanes, L.; Zuniga, S. Mutagenesis of Coronavirus nsp14 Reveals Its Potential Role in Modulation of the Innate Immune Response. J. Virol. 2016, 90, 5399-5414. [CrossRef] [PubMed]

94. Eckerle, L.D.; Lu, X.; Sperry, S.M.; Choi, L.; Denison, M.R. High fidelity of murine hepatitis virus replication is decreased in nsp14 exoribonuclease mutants. J. Virol. 2007, 81, 12135-12144. [CrossRef] [PubMed]

95. Eckerle, L.D.; Becker, M.M.; Halpin, R.A.; Li, K.; Venter, E.; Lu, X.T.; Scherbakova, S.; Graham, R.L.; Baric, R.S.; Stockwell, T.B.; et al. Infidelity of SARS-CoV Nsp14-Exonuclease Mutant Virus Replication Is Revealed by Complete Genome Sequencing. PLoS Pathog. 2010, 6, e1000896. [CrossRef] [PubMed]

96. Marcotrigiano, J.; Gingras, A.C.; Sonenberg, N.; Burley, S.K. Cocrystal structure of the messenger RNA $5^{\prime}$ cap-binding protein (eIF4E) bound to 7-methyl-GDP. Cell 1997, 89, 951-961. [CrossRef]

97. Decroly, E.; Ferron, F.; Lescar, J.; Canard, B. Conventional and unconventional mechanisms for capping viral mRNA. Nat. Rev. Microbiol. 2012, 10, 51-65. [CrossRef]

98. Bouvet, M.; Imbert, I.; Subissi, L.; Gluais, L.; Canard, B.; Decroly, E. RNA 3 '-end mismatch excision by the severe acute respiratory syndrome coronavirus nonstructural protein nsp10/nsp14 exoribonuclease complex. Proc. Natl. Acad. Sci. USA 2012, 109, 9372-9377. [CrossRef]

99. Derbyshire, V.; Grindley, N.D.F.; Joyce, C.M. The $3^{\prime}-5^{\prime}$ Exonuclease of DNA-Polymerase-I of Escherichia-Coli-Contribution of Each Amino-Acid at the Active-Site to the Reaction. EMBO J. 1991, 10, 17-24. [CrossRef]

100. Romano, M.; Squeglia, F.; Berisio, R. Structure and Function of RNase AS: A Novel Virulence Factor From Mycobacterium tuberculosis. Curr. Med. Chem. 2015, 22, 1745-1756. [CrossRef] [PubMed]

101. Romano, M.; van de Weerd, R.; Brouwer, F.C.; Roviello, G.N.; Lacroix, R.; Sparrius, M.; van den Brink-van Stempvoort, G.; Maaskant, J.J.; van der Sar, A.M.; Appelmelk, B.J.; et al. Structure and function of RNase AS, a polyadenylate-specific exoribonuclease affecting mycobacterial virulence in vivo. Structure 2014, 22, 719-730. [CrossRef]

102. Minskaia, E.; Hertzig, T.; Gorbalenya, A.E.; Campanacci, V.; Cambillau, C.; Canard, B.; Ziebuhr, J. Discovery of an RNA virus 3 ' $>5$ ' exoribonuclease that is critically involved in coronavirus RNA synthesis. Proc. Natl. Acad. Sci. USA 2006, 103, 5108-5113. [CrossRef] [PubMed] 
103. Calvanese, L.; Squeglia, F.; Romano, M.; D’Auria, G.; Falcigno, L.; Berisio, R. Structural and dynamic studies provide insights into specificity and allosteric regulation of ribonuclease as, a key enzyme in mycobacterial virulence. J. Biomol. Struct. Dyn. 2019, 1-13. [CrossRef] [PubMed]

104. Denison, M.R.; Graham, R.L.; Donaldson, E.F.; Eckerle, L.D.; Baric, R.S. Coronaviruses an RNA proofreading machine regulates replication fidelity and diversity. RNA Biol. 2011, 8, 270-279. [CrossRef] [PubMed]

105. Tchesnokov, E.P.; Obikhod, A.; Schinazi, R.F.; Gotte, M. Delayed chain termination protects the anti-hepatitis B virus drug entecavir from excision by HIV-1 reverse transcriptase. J. Biol. Chem. 2008, 283, 34218-34228. [CrossRef] [PubMed]

106. Dulin, D.; Arnold, J.J.; van Laar, T.; Oh, H.S.; Lee, C.; Perkins, A.L.; Harki, D.A.; Depken, M.; Cameron, C.E.; Dekker, N.H. Signatures of Nucleotide Analog Incorporation by an RNA-Dependent RNA Polymerase Revealed Using High-Throughput Magnetic Tweezers. Cell Rep. 2017, 21, 1063-1076. [CrossRef]

107. Smith, E.C.; Blanc, H.; Surdel, M.C.; Vignuzzi, M.; Denison, M.R. Coronaviruses lacking exoribonuclease activity are susceptible to lethal mutagenesis: Evidence for proofreading and potential therapeutics. PLoS Pathog. 2013, 9, e1003565. [CrossRef]

108. Morse, J.S.; Lalonde, T.; Xu, S.; Liu, W.R. Learning from the Past: Possible Urgent Prevention and Treatment Options for Severe Acute Respiratory Infections Caused by 2019-nCoV. Chembiochem 2020, 21, 730-738. [CrossRef]

109. Rao, S.T.; Rossmann, M.G. Comparison of super-secondary structures in proteins. J. Mol. Biol. 1973, 76, 241-256. [CrossRef]

110. Byszewska, M.; Smietanski, M.; Purta, E.; Bujnicki, J.M. RNA methyltransferases involved in $5^{\prime}$ cap biosynthesis. RNA Biol. 2014, 11, 1597-1607. [CrossRef]

111. Chouhan, B.P.S.; Maimaiti, S.; Gade, M.; Laurino, P. Rossmann-Fold Methyltransferases: Taking a "beta-Turn” around Their Cofactor, S-Adenosylmethionine. Biochemistry 2019, 58, 166-170. [CrossRef]

112. Schubert, H.L.; Blumenthal, R.M.; Cheng, X.D. Many paths to methyltransfer: A chronicle of convergence. Trends Biochem. Sci. 2003, 28, 329-335. [CrossRef]

113. Chen, Y.; Cai, H.; Pan, J.; Xiang, N.; Tien, P.; Ahola, T.; Guo, D.Y. Functional screen reveals SARS coronavirus nonstructural protein nsp14 as a novel cap N7 methyltransferase. Proc. Natl. Acad. Sci. USA 2009, 106, 3484-3489. [CrossRef] [PubMed]

114. Chen, Y.; Tao, J.L.; Sun, Y.; Wu, A.D.; Su, C.Y.; Gao, G.Z.; Cai, H.; Qiu, S.; Wu, Y.L.; Ahola, T.; et al. Structure-Function Analysis of Severe Acute Respiratory Syndrome Coronavirus RNA Cap Guanine-N7-Methyltransferase. J. Virol. 2013, 87, 6296-6305. [CrossRef]

115. Jin, X.; Chen, Y.; Sun, Y.; Zeng, C.; Wang, Y.; Tao, J.L.; Wu, A.D.; Yu, X.; Zhang, Z.; Tian, J.; et al. Characterization of the guanine-N7 methyltransferase activity of coronavirus nsp14 on nucleotide GTP. Virus Res. 2013, 176, 45-52. [CrossRef]

116. Jankowsky, E.; Fairman, M.E. RNA helicases-one fold for many functions. Curr. Opin. Struct. Biol. 2007, 17, 316-324. [CrossRef]

117. Deng, Z.; Lehmann, K.C.; Li, X.; Feng, C.; Wang, G.; Zhang, Q.; Qi, X.; Yu, L.; Zhang, X.; Feng, W.; et al. Structural basis for the regulatory function of a complex zinc-binding domain in a replicative arterivirus helicase resembling a nonsense-mediated mRNA decay helicase. Nucleic Acids Res. 2014, 42, 3464-3477. [CrossRef]

118. Ivanov, K.A.; Ziebuhr, J. Human coronavirus 229E nonstructural protein 13: Characterization of duplex-unwinding, nucleoside triphosphatase, and RNA 5'-triphosphatase activities. J. Virol. 2004, 78, 7833-7838. [CrossRef]

119. Adedeji, A.O.; Lazarus, H. Biochemical Characterization of Middle East Respiratory Syndrome Coronavirus Helicase. mSphere 2016, 1, e00235-16. [CrossRef]

120. Adedeji, A.O.; Marchand, B.; Te Velthuis, A.J.; Snijder, E.J.; Weiss, S.; Eoff, R.L.; Singh, K.; Sarafianos, S.G. Mechanism of nucleic acid unwinding by SARS-CoV helicase. PLoS ONE 2012, 7, e36521. [CrossRef]

121. Ziebuhr, J. The coronavirus replicase. Curr. Top Microbiol. Immunol. 2005, 287, 57-94. [CrossRef]

122. Van Dinten, L.C.; van Tol, H.; Gorbalenya, A.E.; Snijder, E.J. The predicted metal-binding region of the arterivirus helicase protein is involved in subgenomic mRNA synthesis, genome replication, and virion biogenesis. J. Virol. 2000, 74, 5213-5223. [CrossRef] [PubMed] 
123. Adedeji, A.O.; Singh, K.; Calcaterra, N.E.; DeDiego, M.L.; Enjuanes, L.; Weiss, S.; Sarafianos, S.G. Severe acute respiratory syndrome coronavirus replication inhibitor that interferes with the nucleic acid unwinding of the viral helicase. Antimicrob. Agents Chemother. 2012, 56, 4718-4728. [CrossRef] [PubMed]

124. Adedeji, A.O.; Singh, K.; Kassim, A.; Coleman, C.M.; Elliott, R.; Weiss, S.R.; Frieman, M.B.; Sarafianos, S.G. Evaluation of SSYA10-001 as a replication inhibitor of severe acute respiratory syndrome, mouse hepatitis, and Middle East respiratory syndrome coronaviruses. Antimicrob. Agents Chemother. 2014, 58, 4894-4898. [CrossRef]

125. Aouadi, W.; Blanjoie, A.; Vasseur, J.J.; Debart, F.; Canard, B.; Decroly, E. Binding of the Methyl Donor S-Adenosyl-L-Methionine to Middle East Respiratory Syndrome Coronavirus 2 '-O-Methyltransferase nsp16 Promotes Recruitment of the Allosteric Activator nsp10. J. Virol. 2017, 91, e02217-16. [CrossRef] [PubMed]

126. Martin, J.L.; McMillan, F.M. SAM (dependent) I AM: The S-adenosylmethionine-dependent methyltransferase fold. Curr. Opin. Struc. Biol. 2002, 12, 783-793. [CrossRef]

127. Joseph, J.S.; Saikatendu, K.S.; Subramanian, V.; Neuman, B.W.; Brooun, A.; Griffith, M.; Moy, K.; Yadav, M.K.; Velasquez, J.; Buchmeier, M.J.; et al. Crystal structure of nonstructural protein 10 from the severe acute respiratory syndrome coronavirus reveals a novel fold with two zinc-binding motifs. J. Virol. 2006, 80, 7894-7901. [CrossRef]

128. Matthes, N.; Mesters, J.R.; Coutard, B.; Canard, B.; Snijder, E.J.; Moll, R.; Hilgenfeld, R. The non-structural protein Nsp10 of mouse hepatitis virus binds zinc ions and nucleic acids. FEBS Lett. 2006, 580, 4143-4149. [CrossRef]

129. Zust, R.; Cervantes-Barragan, L.; Habjan, M.; Maier, R.; Neuman, B.W.; Ziebuhr, J.; Szretter, K.J.; Baker, S.C.; Barchet, W.; Diamond, M.S.; et al. Ribose 2'-O-methylation provides a molecular signature for the distinction of self and non-self mRNA dependent on the RNA sensor Mda5. Nat. Immunol. 2011, 12, 137-143. [CrossRef]

130. Devarkar, S.C.; Wang, C.; Miller, M.T.; Ramanathan, A.; Jiang, F.; Khan, A.G.; Patel, S.S.; Marcotrigiano, J. Structural basis for $\mathrm{m} 7 \mathrm{G}$ recognition and 2'-O-methyl discrimination in capped RNAs by the innate immune receptor RIG-I. Proc. Natl. Acad. Sci. USA 2016, 113, 596-601. [CrossRef]

131. Hyde, J.L.; Diamond, M.S. Innate immune restriction and antagonism of viral RNA lacking 2-O methylation. Virology 2015, 479-480, 66-74. [CrossRef]

132. Daffis, S.; Szretter, K.J.; Schriewer, J.; Li, J.; Youn, S.; Errett, J.; Lin, T.Y.; Schneller, S.; Zust, R.; Dong, H.; et al. 2'-O methylation of the viral mRNA cap evades host restriction by IFIT family members. Nature 2010, 468, 452-456. [CrossRef] [PubMed]

133. Diamond, M.S.; Farzan, M. The broad-spectrum antiviral functions of IFIT and IFITM proteins. Nat. Rev. Immunol. 2013, 13, 46-57. [CrossRef] [PubMed] 